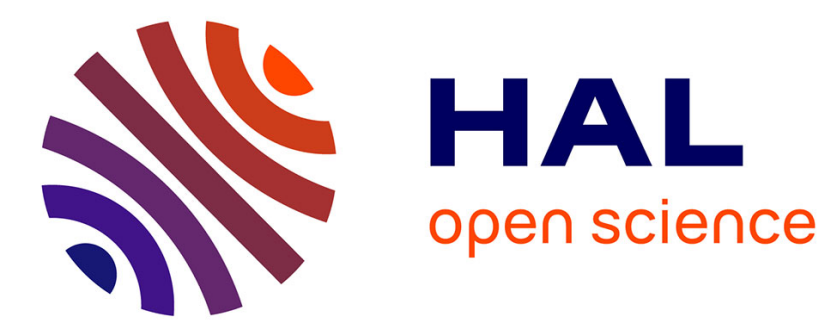

\title{
Export price adjustments under financial constraints
}

Angelo Secchi, Federico Tamagni, Chiara Tomasi

\section{To cite this version:}

Angelo Secchi, Federico Tamagni, Chiara Tomasi. Export price adjustments under financial constraints. 2013. halshs-00848159v2

\section{HAL Id: halshs-00848159 \\ https://shs.hal.science/halshs-00848159v2}

Submitted on 31 Jan 2014

HAL is a multi-disciplinary open access archive for the deposit and dissemination of scientific research documents, whether they are published or not. The documents may come from teaching and research institutions in France or abroad, or from public or private research centers.
L'archive ouverte pluridisciplinaire HAL, est destinée au dépôt et à la diffusion de documents scientifiques de niveau recherche, publiés ou non, émanant des établissements d'enseignement et de recherche français ou étrangers, des laboratoires publics ou privés. 


\section{Documents de Travail du Centre d'Economie de la Sorbonne}

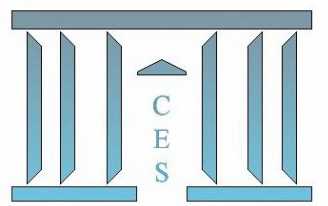

Export price adjustments under financial constraints

Angelo SECCHI, Federico TAMAGNI, Chiara TOMASI

2013.57

Version révisée

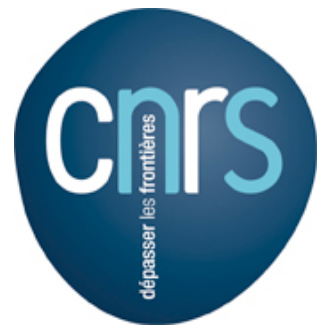

Maison des Sciences Économiques, 106-112 boulevard de L'Hôpital, 75647 Paris Cedex 13 http://centredeconomiesorbonne.univ-paris1.fr/bandeau-haut/documents-de-travail// 


\title{
Export price adjustments under financial constraints
}

\author{
Angelo Secchi ${ }^{\mathrm{a}}$, Federico Tamagni ${ }^{\mathrm{b}}$, and Chiara Tomasi ${ }^{\mathrm{c}}$

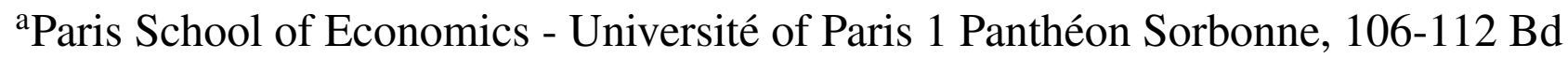 \\ de l'Hopital, 75013 Paris, France. \\ ${ }^{\mathrm{b}}$ Corresponding author: Institute of Economics, Scuola Superiore Sant'Anna, \\ Piazza Martiri 33, 56126 Pisa, Italy, E-mail f.tamagni@sssup.it, \\ $\mathrm{Tel}+39-050-883343$.
}

${ }^{\mathrm{c}}$ Department of Economics University of Trento, via Inama 5, 38122 Trento, Italy.

January 17, 2014

\begin{abstract}
Exploiting data on product-destination level transactions of a large panel of Italian firms, we provide new evidence on the effect of financial constraints on price variation across exporters. Controlling for firm characteristics and endogeneity, constrained exporters charge higher prices than unconstrained firms exporting in the same product-destination market. The positive price difference increases with horizontal differentiation of products, while it reduces in vertically differentiated products, where there is more scope for quality adjustments. The results are consistent with constrained firms exploiting demand rigidities to keep prices up in the attempt to sustain revenues and escape the constraints.
\end{abstract}

JEL codes: F10, F14, F36, G20, G32, L25

Keywords: financial constraints, export prices, horizontal and vertical differentiation, quality adjustment 


\section{Introduction}

Informational asymmetries and imperfect screening in capital or credit markets give raise to situations where financing constraints prevent potentially successful and growth enhancing projects or businesses to be undertaken. There are a few reasons why access to finance plays a particularly important role for firms involved in export activities (Manova et al., 2011). Fixed and variable costs tend to be higher for exporters than for domestic producers, due to the need to build ad-hoc distributional networks, to acquire specific information on destination markets, to customize products, or to the mere transportation of goods. Moreover, the time lag between production and the actual realization of the corresponding revenues is typically longer for exporters, and international sales contracts are usually more complex, riskier and less enforceable than the domestic ones. It is building upon these ideas that an increasing number of empirical papers has recently focused on the effects of financial frictions on firms' export activities. The bulk of these works focus on extensive and intensive margins of exports, showing that financial constraints are critical determinants of trade in many respects. Constraints reduce firms' ability to enter international markets and the volume of trade, and limit the exporters' product scope as well as the number of trade partners. ${ }^{1}$

The relationship between constraints or credit markets imperfections and export prices is much less investigated, and this is particularly unfortunate. First, there is no reason why one should only focus on the margins of exports, as indeed financial constraints can distort firms' pricing strategies just as they affect firms' choices along the extensive and intensive margins. And actually, adjusting prices represent in a sense an even more natural strategic instrument in response to financing problems. Indeed changing prices is in principle faster and easier than adjusting capacity, quantities or the scope of product/geographical diversification, although of course a number of factors such as the strength of competition, demand characteristics, quality and others might all influence the scope to maneuver on prices effectively.

Second, understanding the influence of constraints on export pricing is of great relevance also for the impact likely induced at the aggregate industry or economy-wide level. Indeed, the growing literature on firms' heterogeneity in international trade emphasizes that changes in prices play a crucial role in linking trade liberalization to aggregate productivity dynamics. Fiercer import competition induced by the opening up of trade forces firms to adjust prices and profits, triggering a process of market shares reallocation that leads to sectoral productivity improvements. By affecting export prices, financial frictions may influence this reallocation process. Moreover, recent evidence linking micro patterns to macro dynamics suggests that financial constraints cause firms to contribute to the exchange rate disconnect (Strasser, 2013). Indeed, export prices of financially constrained firms are more sensitive to exchange rate fluctuations, with important implications not only for firms' competitiveness, but also for monetary policy, macroeconomic stability, and more generally for the welfare

\footnotetext{
${ }^{1}$ Consistent results are presented in Muuls (2008) for Belgium, in Bellone et al. (2010) for France, in Minetti and Zhu (2011) for a cross-section of Italian firms, and in Li and Yu (2009) and Manova et al. (2011) for Chinese firms. The only contrasting evidence is in Greenaway et al. (2007) for UK, where the probability of entry into exporting is not affected by financing problems, and in Berman and Hricourt (2010), where financing problems do not influence export values in a sample of nine developing countries.
} 
of producers and consumers. ${ }^{2}$

This paper contributes to the literature by providing an exhaustive analysis of the role that limited access to external finance plays in influencing price variation across exporting firms and by uncovering the main factors operating behind this relationship. The work exploits an original Italian database obtained by merging balance sheets information with a transaction-level dataset recording custom information on values and quantities involved in each export transaction performed by a firm, broken down by product and destination country. The key advantage of our dataset is that it includes both a proxy of the price charged by each firm for each product-destination transaction, and an informative firm-level measure of access to credit. The latter is based on a credit rating index internal to and heavily used within the Italian banking system, and available for all the firms in the dataset. Compared to alternative proxies of financial constraints, either based on firm financial conditions measured through balance sheets variables or on surveys eliciting whether firms perceived themselves as constrained, credit ratings can provide a cleaner identification of the actual situation where a firm faces an inelastic credit supply schedule, and no possibility to resort to external finance. Indeed, by incorporating the credit markets' view and attitude towards potential borrowers, credit ratings measure the actual way investors' decide to provide external finance. Some peculiar features of the specific rating index used in the paper make it particularly relevant and tightly linked with the supply and cost of credit.

While few other recent works look at the relationship between financial constraints and export pricing, this paper represents, to the best of our knowledge, the only attempt to explicitly control for possible endogeneity bias due to omitted variables or reverse causality. To overcome these potential problems and to achieve a proper identification, we adopt an instrumental variable strategy. Following an established practice in the empirical studies on Italy, we use historical information about changes in the Italian banking regulation to identify exogenous variation to the local (province level) supply of banking services (Guiso et al., 2004; Minetti and Zhu, 2011). Precisely, we resort to exogenous variation in provincial credit supply determined by the progressive removal, during the 1990s, of a series of restrictions to banking services introduced in 1936 by the Bank of Italy.

Our main result is that financial constraints play a relevant role in influencing export pricing. Firms facing tighter credit conditions charge higher prices than unconstrained firms exporting an equal product to the same destination. Such "price-premium" for constrained exporters holds even when controlling for a set of firm-level characteristics, and it is robust to a series of sensitivity analyses concerning different validations of the instruments and different sub-samples.

This finding can be interpreted in light of the price-constraints link predicted by diverse theories. Outside the international trade literature, models of competition in markets with demand rigidities (see Klemperer, 1995, for a review) stress that charging higher prices is just a way, for firms facing shortage of credit, to fulfill the need to keep operations and meet current liabilities. The key point is that there must be strong enough frictions in the product market allowing to increase prices without loosing too much of the demand, at least in the short run. Within the micro-trade literature, models extending the standard Melitz (2003) framework (see Fan et al., 2012, for a framework encompassing

\footnotetext{
${ }^{2}$ The current crisis and the related contraction of international trade make the investigation of the mechanisms relating finance to firm's export pricing even more topical. See Amiti and Weinstein (2011), Levchenko et al. (2010), Feenstra et al. (2011) and Chor and Manova (2012) for recent evidence of the role of financial constraints in restricting trade flows.
} 
other attempts) suggest that two opposing channels shape the impact of financial constraints on export prices. A price distortion effect that, similarly to the demand-friction mechanism, comes from the ability of constrained firms to charge higher prices exploiting product market rigidities. And a quality adjustment effect: constrained firms cannot afford the costs of quality and thus sell lower quality goods at lower prices. Finally, one can envisage a third mechanism, common to all theories: a simple costs effect inducing constrained firms to set higher export prices just because they operate at higher unit costs.

We find that the price premium for constrained firms survives after controlling for the costs channel. Further, we show that the price premium for constrained firms is larger in more horizontally differentiated products, where one expects that there is more room to leverage on price rigidities, while it is smaller, although still positive, in more vertically differentiated products, where there is more scope for quality adjustment. Overall, therefore, the findings suggest that both the price distortions related to demand rigidities and the quality adjustment effect play a role, but the distortion effect is dominant. This represents a challenge for existing trade models, as they can explain this result only within a framework where quality is exogenous.

Within the vast empirical literature on firm heterogeneity in international trade, this article more directly relates to the scarce works that focus on the impact of financial frictions on pricing strategies. Manova et al. (2011), using Chinese custom data, find two contrasting results: while MNC affiliates set lower export prices in financially vulnerable sectors, joint ventures have higher unit values in the same industries. Fan et al. (2012), using the same data, provide evidence that firms in sectors with higher external finance dependence set, on average, lower prices. These papers rely on industry-level rather than on firm-level measures of financial constraints, and do not control for possible endogeneity of financial constraints. Our analysis overcomes both limitations.

The work also relates to the growing empirical literature documenting the systematic variation in export prices across firms, products and trade partners (Bastos and Silva, 2010; Manova and Zhang, 2012a; Harrigan et al., 2011; Fan et al., 2012). These studies directly link export prices to firm characteristics including productivity, size, capital intensity, and the skill composition of workers. By contrast, our study reveals that firm financial conditions represent a further crucial determinant of product-destination export prices.

\section{Data and descriptive analysis}

This Section presents the data and provides descriptive evidence on the relationship between the proxy of financial constraints (FCs) and the main variables.

\section{The Data}

The analysis combines three sources of data: the Italian Foreign Trade Statistics (Commercio Estero, hereafter COE) and the Italian Register of Active Firms (Archivio Statistico Imprese Attive, ASIA), both collected by the Italian Statistical Office (ISTAT), and a firm level accounting dataset, which is 
available through ISTAT but collected by the Italian Company Account Data Service (Centrale dei Bilanci, CB). ${ }^{3}$

The major advantage of matched firm-trade data is that they enable to directly relate export prices to firm attributes. The COE dataset is the official register of all trade flows of Italy. It records separately the value (in Euros) and the quantity (in kilos) involved in each export and import crossborder transaction performed by a firm, thus allowing to compute export and import prices (unit values). As standard with this kind of custom-level data, we compute unit values as the ratio between the value and the physical quantity of each export transaction. Because the reported value of exports excludes the cost of insurance and freight, the unit price of exports is a free-on-board (f.o.b) price. ${ }^{4}$ Traded products are classified at the six digit level of the Harmonised System (HS6) classification. The data available to the present study cover the period 2000-2003, for a total of 5,329 product categories exported in 236 different destination countries.

The ASIA register covers the universe of Italian firms active in the same time span, irrespective of their export status. It reports annual figures on number of employees, sector of main activity (according to European NACE industrial classification) and geographical location of the firms (municipality of principal activity or legal address).

The CB dataset collects annual administrative reports for all Italian limited liability firms. The long term institutional role of $\mathrm{CB}$ ensures high data quality, limiting measurement error. ${ }^{5}$

By merging these three data sources, we obtain a dataset that covers the entire population of Italian limited firms (exporters and non exporters) over the period 2000-2003. We focus on manufacturing firms. Compared to the overall population of manufacturing firms, in 2003 our dataset covers $21 \%$ of firms, about $59 \%$ of all manufacturers that do export, and $84 \%$ of the total value of exports, and similar values are observed for the other years. The main limitation of the sample rests in a mild over-representation of bigger and more productive firms. ${ }^{6}$

Further, since the short time span available and the inclusion of lagged variables place limits to the exploitation of time variation, our main analysis considers time-series averages of the relevant variables between 2000-2001 and between 2002-2003, respectively for those variables entering in the regression models at time $t-1$ and $t$. This avoids an arbitrary choice of a single year, and allows to smooth for possible individual year shocks. The final sample includes a total of 117, 747 firms.

Column 2 of Table 1 presents descriptive statistics about the sample characteristics in terms of key control variables employed in the following regression analysis. These include size measured by the number of employees, age computed by the year of foundation, a TFP measure (in logs) obtained via the IV-GMM modified Levinsohn-Petrin estimator proposed in Wooldridge (2009), and two variables

\footnotetext{
${ }^{3}$ The data were accessed at the ISTAT facilities in Rome, and have been made available after careful screening to avoid disclosure of individual information.

${ }^{4}$ ISTAT collects data on exports based on individual transactions. The European Union sets common rules for data collection across countries, but leaves some flexibility to member states. See the Appendix for a detailed description of requirements for inclusion in the Italian export data.

${ }^{5} \mathrm{CB}$ was founded as a joint agency of the Bank of Italy and the Italian Banking Association in the early 1980s to assist in supervising risk exposure of the Italian banking system. Today part of the leading group in business information services in Italy, during the sample period CB was a private company owned by major Italian banks which exploited its services in gathering and sharing information about firms.

${ }^{6}$ See Tables A1 and A2 in the Appendix for further details on the data sources and their coverage.
} 
Table 1: DESCRIPTIVE STATISTICS

\begin{tabular}{lccc}
\hline \hline & $\begin{array}{c}\text { Our sample - Number } \\
\text { of firms } \\
(1)\end{array}$ & $\begin{array}{c}\text { Our sample } \\
\text { Averages } \\
(2)\end{array}$ & $\begin{array}{c}\text { Difference between FC } \\
\text { and non-FC firms }\end{array}$ \\
\hline Panel A - All firms & & & $(3)$ \\
Number of firms & 117,747 & & \\
Number of FC firms & 20,598 & & $-0.610^{* * *}(0.013)$ \\
Number of employees & & 27.141 & $-0.492^{* * *}(0.008)$ \\
Age & & 14.494 & $-0.436^{* * *}(0.009)$ \\
log TFP & & 2.588 & $-0.755^{* * *}(0.012)$ \\
Total Assets & 6,209 & $-2.258^{* * *}(0.016)$ \\
Gross operating margin & & 566.3 & \\
Panel B - Exporters & & & \\
Number of firms & & & \\
Number of FC firms & 53,174 & & \\
Number of employees & 6,815 & & $-0.709^{* * *}(0.017)$ \\
Age & & & $-0.555^{* * *}(0.014)$ \\
log TFP & & 47.777 & $-0.453^{* * *}(0.013)$ \\
Total Assets & 17.471 & $-0.679^{* * * *}(0.019)$ \\
Gross operating margin & & 2.772 & $-2.552^{* * *}(0.029)$ \\
\hline
\end{tabular}

Notes:

Panel A - Column 1: number of firms and number of FC firms in the sample, all years. Column 2: 2000-2001 averages of number of employees, age, Wooldridge (2009) modified Levinsohn-Petrin TFP, total assets, and gross operating margins, all computed across all firms in the sample. Column 3: difference in means between constrained and unconstrained firms in the sample via log-OLS regressions of 2000-2001 averages of firms' characteristics on the FC dummy, controlling for 3-digit industry.

Panel B - Column 1: number of exporters and number of FC exporters in the sample, all years. Column 2: 20002001 averages of number of employees, age, Wooldridge (2009) modified Levinsohn-Petrin TFP, total assets, and gross operating margins, all computed across exporting firms in the sample. Column 3: difference in means between constrained vs. unconstrained exporters via log-OLS regressions of 2000-2001 averages of firms' characteristics on the FC dummy, controlling for 3-digit industry.

Robust standard error in parenthesis. ***: significant at the $1 \%$ level; **: significant at the $5 \%$ level; *: significant at the $10 \%$ level. 
that interact with external credit constraints in determining the financial status of a firm. ${ }^{7}$ These are total assets to proxy for availability of collateral, and gross operating margins as a measure of internally generated resources. Comparing all firms vs. exporting firms (Panel A vs. Panel B), we confirm the stylised facts that exporters are on average bigger, older and more productive. Also, they have a stronger financial side, with more assets and more internal resources.

\section{Measuring financial constraints}

Our assessment of firm-level financing constraints is based on a firm-specific credit rating issued yearly by $\mathrm{CB}$. This rating is the result of an in-depth analysis conducted by professional analysts, complementing hard data on borrowers with relevant soft information collected locally. ${ }^{8}$ The construction of the credit rating follows two steps. A first step consists in the development of a score based on a broad set of qualitative and quantitative variables. ${ }^{9}$ Second, a group of analysts combines this score with additional information collected locally through direct contacts with the company and with other relevant institutional and market operators. The resulting index is given on a scale of 9 categories of creditworthiness: 1-high reliability, 2-reliability, 3-ample solvency, 4-solvency, 5-vulnerability, 6-high vulnerability, 7-risk, 8-high risk, and 9-extremely high risk.

The traditional difficulty in measuring financial constraints originates in the usual inability to observe when the credit supply schedule faced by a firm becomes inelastic, so that the option to resort to external financial resources is ruled out. To overcome this measurement problem, the literature proposes a few indirect proxies of FC based either on what firms say and perceive, or on data coming from their balance sheets and financial statements. As Farre-Mensa and Ljungqvist (2013) explain, the common identification assumption underlying all these approaches is "that managers' words or actions reflect the shape of the credit supply curve as they perceive it." Credit ratings, in general, and the $\mathrm{CB}$ rating in particular represent a valid alternative proxy for FCs since they capture the shape of a firm's credit supply curve as the credit market perceives it. Let us explain why we believe this is the case.

First, the $\mathrm{CB}$ rating works as an official rating internal to the Italian credit system, widely used and benchmarked by Italian banks in the evaluation of potential borrowers. The tight link with the banking system is crucial. In fact, although the Italian banking system is comparatively small with respect to the real economy (2.7 times the GDP compared to, for instance, 4.2 times the GDP in France), bank credit plays a prominent role as a source of financing of firms in Italy. Almost $70 \%$ of the financial debts of non-financial corporations is made up by bank loans, while the same share is

\footnotetext{
${ }^{7}$ In applying the Wooldridge (2009) TFP estimator, we take value added as a proxy for output, employees and gross tangible assets to proxy for labour and capital inputs, respectively, and cost of material inputs as a proxy for intermediate inputs. Here and in the following, variables are deflated with appropriate sectoral price indexes collected by ISTAT. Complete deflator series are available only at the 2-digit level. We therefore perform deflation at this level of aggregation. The base year is 2000 .

${ }^{8}$ Soft information refers to any kind of data other than the relative transparent public information about the firm such as the availability of collateral or other balance sheet data. See Petersen (2004) for a discussion on soft vs. hard information. Detailed information is available at http://www.cervedgroup.com .

${ }^{9}$ These include i) financial statement figures combined with geographical and sector-specific risk components; ii) qualitative indicators concerning a company's market share positioning, quality of governance and prospects for the future; iii) behavioral evaluation based on punctuality in payments to suppliers, default of payments or other credit events.
} 
only 37\% in France and 55\% in Germany (see Figure A1 in the Appendix). By contrast, Italian capital and bond markets are quite small compared to other major countries. The stock market capitalization of Italian non financial corporations is less that $20 \%$ of GDP, compared with $75 \%$ in France and $45 \%$ in Germany (Figure A2 in the Appendix). Bond financing of Italian non financial corporations amounts to less than $8 \%$ of firms' total financial debt (Figure A3 in the Appendix). ${ }^{10}$

Second, the CB index works well as a proxy for what banks do. Previous empirical analyses indeed show that there is a tight link between the $\mathrm{CB}$ rating and the availability and the cost of external finance. Guiso et al. (2013) provide clear evidence that, ceteris paribus, bad ratings have a clear association with higher interest rates and thus, with the cost of credit. Panetta et al. (2009) show that it is unlikely that a firm with poor rating can receive any credit. ${ }^{11}$

Third, the CB index does not merely work as a summary measure of firm performance. Indeed, previous empirical analyses (Bottazzi et al., 2008, 2013) corroborate the complex and rich informational content of the index, showing that an important fraction of highly productive, highly profitable and fast growing firms receive very poor scores.

In the attempt to exploit the $\mathrm{CB}$ rating to identify firms likely to face an inelastic credit supply curve, we build a financial constraints dummy (FC) that looks at the worst rating situation over the relevant time span. Specifically, given the time-series average structure of the data and since we will be using lagged FC status in the empirical models, we take the maximum (i.e. the worst) rating assigned to each firm between 2000 and 2001, and build a dummy that equals 1 if the max rating is 8 or 9 , and 0 otherwise. ${ }^{12}$ This choice is in line with the recent evidence by Farre-Mensa and Ljungqvist (2013) showing that only the very poorly rated firms do experience a vertical credit supply curve. ${ }^{13}$

According to our definition, the percentage of firms defined as FC firms is $17.5 \%$ of the whole sample. The same ratio is $12.8 \%$ for exporters, and $21.3 \%$ for non-exporters. ${ }^{14}$ Figure A4 in Appendix shows the geographical distribution of FC firms across Italian provinces. Notwithstanding the relatively lower presence of FC firms in Northern provinces, rationed firms are not clustered in few

\footnotetext{
${ }^{10}$ Further indirect support to the importance of the banking system for external financial resources in Italy comes from the SAFE survey run by the ECB. In the May 2009 wave only about $25 \%$ of Italian SMEs declared that they did not apply for a bank loan (new or renewal) because of sufficient internal funds.

${ }^{11}$ More generally, in the empirical literature about the micro-economic assessment of financial constraints the supply of bank loans is modeled as a function of different parameters including, when available, a firm's credit rating. Kremp and Sevestre (2012), for instance, include in the supply equation for new loans not only financial indicators but also the firm rating developed by the Bank of France that is made available to private banks for their lending activity.

${ }^{12}$ Similar results, available upon request, are obtained if we take the average of the rating over the two years. Note also that, as an ordinal variable, it would be questionable to directly use the 1-9 rating scores among the regressor, as indeed there is no quantitative meaning in moving, for instance, from class 3 to class 5 . The binary categorization, moreover, avoids the potential error in variables problem arising from including dummies for each of the 9 original rating classes. An alternative approach would be to exploit the graduation of scores and build more than two classes. Guiso et al. (2013) insert in their wage regression an intermediate class of Mildly Financially Constrained (MFC) firms defined as rated 46, while Bottazzi et al. (2008) and Bottazzi et al. (2013) include a mid-constrained category of rated 5-7 firms in their analysis of productivity, profitability and growth dynamics of Italian firms. In all of these studies, however, it is only for the class of worst rated firms that one observes statistically significant differences with the rest of the sample.

${ }^{13}$ They indeed find that like our "very poor CB rating" measure, only a dummy capturing if a firm is a "junk bond issuer" works as a proper FC identifier.

${ }^{14}$ These numbers are in line with previous studies on Italy. According to Guiso et al. (2013), firms with a bad rating are $19 \%$ of the entire population. Similar shares are observed by Minetti and Zhu (2011) who use a survey's question as a proxy of financial rationing: $18 \%$ of exporters and $21.6 \%$ of non-exporters are rationed according to their measure.
} 


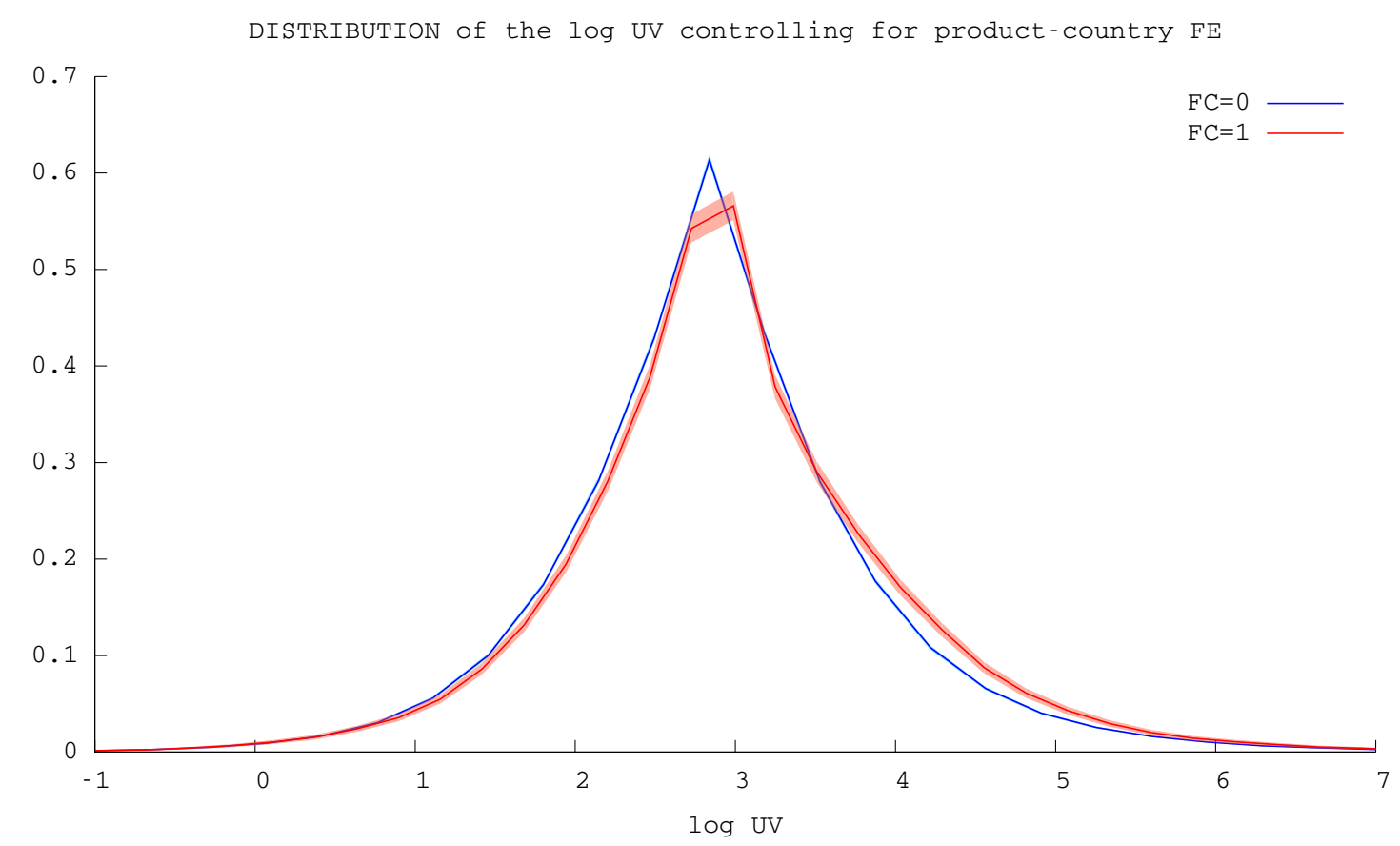

Figure 1: EMPIRICAL DENSITY OF $(\log )$ UNIT VALUES.

Notes: Kernel estimate of the empirical density of the (log) unit values of export transactions performed by constrained (red line) and unconstrained (blue line) exporters, averaged over 2002-2003 and controlling for product-country fixed effects. The kernel function is Epanenchnikov and the bandwidth is set according the standard heuristics in Silverman (1986). A conservative confidence band (confidence level higher than 99\%) is also reported. Stochastic dominance of the density of constrained firms is tested via the Fligner and Policello (1981) test. The value of the test statistics is 26.27 with an associated p-value lower than $10^{-6}$.

local areas. ${ }^{15}$

Column 3 of Table 1 presents basic correlation between the measure of financial constraints and key firm characteristics. We report differences in mean between constrained and unconstrained firms by running an OLS regression of firm attributes (in logs and averaged over 2000-2001) on the FC dummy, including 3-digit industry fixed effects to get rid of sector-specific patterns on the production side. ${ }^{16}$ Looking at the entire sample (in Panel A) we confirm common findings about constrained firms: FC firms tend to be smaller, younger, less productive, and suffer, on average, from a relative weaker financial structure in terms of less assets and less internally generated resources. Once conditioning on being exporters (in Panel B), the results do not change.

Figure 1 provides a first look at our main research question, that is the relationship between FCs and transaction-level prices. We report kernel estimates of the empirical distributions of the (log) unit values of export transactions, averaging over 2002-2003 for the same firm-product-destination triplet, and breaking down the observations by constrained (red line) vs. unconstrained firms (blue line). To avoid mixing together unit values of, e.g., 'pasta' (with a median $0.62 € / \mathrm{Kg}$ ) and 'precious metals' (with a median $17,200 € / \mathrm{Kg}$ ), we plot the distribution in deviation from average values

\footnotetext{
${ }^{15}$ That is, some Southern provinces also present a relatively low share of rationed firms and some Northern provinces have relatively high presence of constrained firms. This is also in line with results in Minetti and Zhu (2011).

${ }^{16}$ Note that the same product can be exported by firms belonging to different industrial sectors, given the imperfect overlap between the classification of traded products (HS6) and the classification of industrial production (NACE).
} 


\begin{tabular}{lcc}
\hline \hline & $(1)$ & $(2)$ \\
& No Controls & Baseline \\
\hline Financially constrained firms dummy (FC) & $0.083^{* * *}(0.004)$ & $0.134^{* * *}(0.004)$ \\
log TFP & & $0.268^{* * *}(0.002)$ \\
log number of employees & & $0.181^{* * *}(0.002)$ \\
log age & & $0.024^{* * *}(0.001)$ \\
log total assets & & $-0.132^{* * *}(0.002)$ \\
log gross operating margin & & $-0.045^{* * *}(0.001)$ \\
North dummy & & $0.103^{* * *}(0.005)$ \\
Center dummy & & $0.106^{* * *}(0.005)$ \\
& $1,825,473$ & \\
Number of observations & Yes & $1,825,473$ \\
Product-Country FE & Yes & Yes \\
3 dgt sectoral dummies & & Yes \\
\hline
\end{tabular}

Notes: The dependent variable is the (log) export unit value at the product-country level. Columns 1 and 2: regressions estimated on the whole sample of exporters. All the regressions include a constant, 3-digit industry dummies and HS6 product-country pair fixed effects (226,812 categories in columns 1-2).

Robust standard errors in parenthesis, clustered at product-country level. ***: significant at the $1 \%$ level; **: significant at the $5 \%$ level; *: significant at the $10 \%$ level.

computed across different firms exporting within the same HS6 product-and-country market (mimicking product-country fixed effects). We compare the two distributions using a non parametric test of stochastic dominance (Fligner and Policello, 1981). The null hypothesis is that the probability that a transaction by a FC firm displays a higher (log) unit value than a transaction by a non-FC firm is higher than $1 / 2$. In case of rejection of the null, the sign of the test statistic tells which group is dominating. In Figure 1 the null is rejected and the positive value of the test statistic (26.27) means that FC firms are more likely to display higher unit values as compared to NFC firms.

\section{Empirical analysis}

This Section moves to regression analysis. We introduce the baseline empirical model and the identification strategy, and then present the main findings.

\section{Empirical model}

The relationship between export prices of Italian manufacturing firms and their FC status is studied through the following baseline regression

$$
\ln \mathrm{EUV}_{f p c, t}=\gamma \mathrm{FC}_{f, t-1}+\mathbf{X}_{f, t-1}^{\prime} \boldsymbol{\beta}+\mu_{p c}+\epsilon_{f p c, t}
$$


where $\mathrm{EUV}_{f p c}$ is the (f.o.b) unit value of product $p$ exported to country $c$ by firm $f$ at time $t$, and the regressor of primary interest is the dummy $\mathrm{FC}_{f, t-1}$, which equals 1 if firm $f$ is financially constrained at time $t-1$ and 0 otherwise. ${ }^{17} \mathbf{X}$ is a set of firm-level controls, all measured at $t-1$. It includes all the variables already presented in the descriptive analysis above. We use the lagged value of firm characteristics to ensure that the estimated coefficients are not contaminated by possible feedback effects of export prices on productivity and other firm attributes. The controls in $\mathbf{X}$ also include a full set of 3-digit industry (NACE codes) dummies, as well as geographical dummies accounting for well known differences in the level of development and other characteristics across Italian macro-areas (North, Center, and South plus Islands). The error term includes HS6 product-destination country fixed effects, $\mu_{p c}$, and a standard random component $\epsilon_{f p c, t}$. Product-destination fixed effects control for all factors common across firms active within the same product-destination pair, including fixed export costs specific to the product variety and the partner country. They therefore also account for product-specific characteristics that are invariant across manufacturers and trade partners, as well as destination-specific economic determinants of prices that affect all products and firms selling there, such as consumer income, bilateral distance, transportation costs, market toughness.

OLS estimates of Equation 1 capture basic correlations. Given product-destination fixed effects, the coefficient of interest $(\gamma)$ is identified purely from the variation of export prices and FC status across firms within the same product-destination market. Results are reported in Table 2, with standard errors clustered at product-country level, but the results are robust to alternative clustering by firm, product, or destination. In column 1, we suppress firm level controls. The estimates confirm the positive correlation of financial constraints with unit values suggested by the distributional analysis presented above. The estimated coefficient tells that the price charged on transactions by constrained firms is on average $8.7 \%$ ( 0.083 log points) higher than the price set in transactions by unconstrained firms exporting the same HS6 product to the same destination market.

In column 2, we introduce firm specific controls. The estimate of $\gamma$ remains positive and the price premium for FC firms increases to $14.3 \%$ (0.134 log points). This implies that failing to control for other firm attributes associates with a downward bias in the FC coefficient. For instance, since it is known (Bastos and Silva, 2010; Berman et al., 2012) that less productive or smaller firms tend to fix lower prices and are also more likely to be constrained, excluding productivity or size from the regression understates the impact of FCs on export prices. With respect to the specification without controls the observed effect is $61 \%$ higher: more than half of the price premium is associated with differences in productivity, size, age, total assets and internal resources between constrained and unconstrained firms.

The estimated coefficient on (log) TFP suggests that a 100 percent increase in productivity is associated with a $30.7 \%(0.268 \mathrm{log}$ points $)$ increase in export prices. The result corroborates previous findings and it is consistent with the endogenous quality theories of trade: more productive firms choose more expensive inputs to produce higher quality goods for which they charge higher prices (Bastos and Silva, 2010; Ge et al., 2013). The coefficient on (log) employees suggests that the price elasticity to firm size is also positive and significant: everything else equal, bigger firms charge higher

\footnotetext{
${ }^{17}$ Recall that $t$ and $t-1$ in represent time averages over 2002-2003 and 2000-2001, respectively, while the $F C_{f, t-1}$ dummy is defined based on the worst rating assigned to the firm between 2000 and 2001.
} 
prices for a product exported in a certain destination (Kugler and Verhoogen, 2012). The magnitude of the association is somewhat smaller than the one observed for productivity: a 100 percent increase in firm size translates into a $19.8 \%$ increase in the export price. The estimated coefficient on age suggests that firms with more experience charge higher export prices. The two financial-side controls both turn out statistically significant and with a negative sign: the greater the availability of collateral or internal resources (and thus the lower the likelihood to be constrained), the lower the price charged for export transactions. The associated percentage reduction in unit values is $14.0 \%$ and $4.6 \%$, respectively. Finally, we observe that firms located in the Center and North of Italy tend to set higher unit values. This is expected, however: given the geographical disparities in Italy, Center-North located firms are typically more innovate and produce higher quality products. ${ }^{18}$

\section{Identification strategy}

There is a concern that our measure of financial constraints could be endogenous, inducing a bias in OLS-FE estimates of the effect of financial constraints on pricing behavior. First, OLS-FE can be biased due to standard omitted variables or measurement error issues, that is if firms characteristics that we do not observe or that we only imperfectly measure generate a variation in export prices and at the same time are correlated with our FC proxy. For instance, it can be that our size or productivity proxies are mis-measured. Since banks are usually more likely to provide credit to larger and more productive firms, which in turn are known to set higher export prices, then we expect the OLS estimates of $\gamma$ to be downward biased. Second, we need to tackle endogeneity due to reverse causality, arising from potential joint determination of the FC status and export prices. Indeed, although information on export prices does not directly enter the construction of the CB rating index, we could expect that overall export strategies of firms might matter for firm ability to access external credit, thus creating a correlation between FC status and export prices.

Although the relatively rich set of controls and detailed product-destination fixed-effects already contribute to absorb a good deal of endogeneity, we adopt an instrumental variable approach. In what follows we define our instrument, explain why we believe it is exogenous and the rationale behind its use, and provide evidence of its correlation with the FC dummy.

In the absence of firm-level alternatives, we consider a provincial level instrument reflecting an exogenous shock to credit supply caused by the progressive removal, during the 1990s, of a series of legal restrictions to provincial-level banking services. As explained in detail in Guiso et al. (2004, 2006), until the 1990s the geographical distribution of banks and bank branches across Italian provinces came about as application of the norms enacted by the regulatory authority in 1936. They were dictating limits to the number of banks and affiliates by province, in a way essentially unrelated to the structural characteristics and the level of development of the provinces themselves.

\footnotetext{
${ }^{18}$ In an unreported regression we suppress averaging over time and exploit the four years panel to estimate the baseline model with firm, product and country fixed effects. The coefficient $\gamma$ in this case is identified purely from the variation of the FC status within a firm across time, controlling for any product and any country characteristic (e.g., an aggregate change in relative demand) that is common across firms. The coefficient, although smaller $(0.010 \log$ points $)$, is positive and statistically significant, supporting that the positive relationship between financial constraints and prices holds even when removing unobserved time-invariant individual heterogeneity. We cannot control for endogeneity in such panel regressions, however, since our instruments do not vary over time (see below).
} 

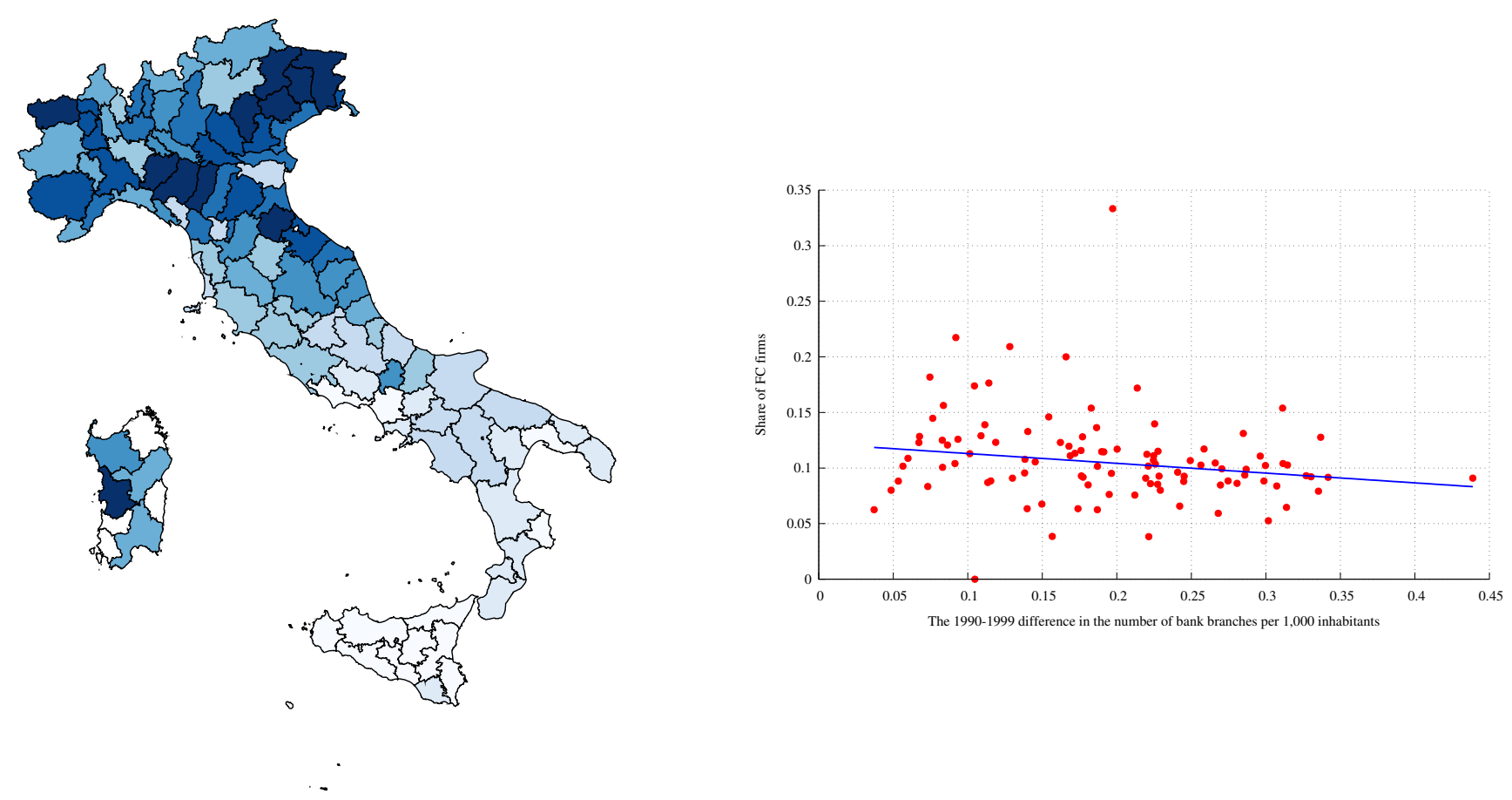

Figure 2: GEOGRAPHICAL DISTRIBUTION OF THE 1990-1999 DIFFERENCE IN THE NUMBER OF BANK BRANCHES (LEFT PANEL) AND ITS RELATION WITH SHARE OF FC FIRMS IN OUR DATA, BY PROVINCE (RIGHT PANEL).

Notes: Plots and fit are based on 103 provincial observations. In the left panel, the darker the province map and the higher the 1990-99 difference in the number of bank branches in that province. In the right panel, the linear fit is a Least Absolute Deviation regression: estimated parameters are $0.121^{* * *}(0.007)$ and $-0.088^{* *}(0.033)$ for the intercept and the slope, respectively. Robust standard errors, ***: significant at the $1 \%$ level.

The subsequent removal of the regulation during the 1990s freed up banks' possibility to open new local affiliates. This exogenous change had differentiated impact across provinces, also in relation to the fact that different types of banks (cooperative or saving banks), unevenly spread across provinces at the time of deregulation, where differently affected by the removal of limitations to open new branches.

Exploiting such historical events, we instrument the FC dummy with the 1990-1999 difference in the number of bank branches (per 1,000 inhabitants) in each province. Similar instruments, based on exogenous change in the geographical distribution of bank branches, originally developed in Guiso et al. (2004), have been recently applied by Minetti and Zhu (2011) to instrument a firm-level proxy of financial constraints. While they study how FCs affect firm-level export margins of a sample of Italian firms, we here extend the investigation to transaction-level export prices. ${ }^{19}$

Key for identification is to clarify the link between the instrument and the CB rating. The main channel through which the instrument could affect credit conditions is via the soft information that is reflected in the credit rating. In general, we expect an increase in local branch density and a lower distance between banks and customer firms to allow banks to gather more precise information,

\footnotetext{
${ }^{19}$ Other empirical analyses on Italy use the geographical distribution of branches in 1936 to instrument provincial level banking variables measuring the local level of financial development. See Herrera and Minetti (2007); Alessandrini et al. (2010); Benfratello et al. (2008).
} 
resulting into more favorable credit ratings. ${ }^{20}$ This stands on two assumptions.

First, an important part of banks' knowledge of potential borrowing firms is not easily codified and therefore it is not easily transmitted far away from where firms are located. Without this information firms look more opaque, and the typical reaction by the banking system is a more conservative and distrustfully approach to evaluation of potential borrowers, an attitude that in turn translates into attaching worse ratings to firms. Second, and relatedly, physical proximity between banks and firms reduces opacity and increases the overall level of trust, for instance through repeated interactions. Eventually, a wider diffusion of local level banking services makes the banks more prone to accept potential borrowers' requests. This should translates into better credit rating scores by banks and by other credit institutions within the banking system.

Supporting this view is the large body of research that recognizes the importance for lending decisions of proximity between banks and borrowers. Petersen and Rajan (1995) show that higher branch density affects firms' credit supply due to the ability of banks to overcome asymmetric information by locally collecting soft information on firms. Bonaccorsi di Patti and Gobbi (2001); Carling and Lundberg (2005) provide evidence that the distance between a firm and a bank branch positively affects the availability of credit. In the Italian case, Alessandrini et al. (2009) show that functional distance and, to some extent, operational proximity between local banking system and local borrowers influence firms' probability of being rationed over the time period 1996-2003. ${ }^{21}$

Therefore, we expect the instrument to capture the variation in the ability of banks to collecting more and more precise information on firms, in turn positively affecting credit ratings and thus reducing financial constraints. By contrast the same variation is not expected to directly impact neither on firm export behavior nor on unobserved firm characteristics that determine export behavior.

Figure 2 provides empirical support to the validity of the instrument. In the left panel we look at the intensity of the 1990-1999 difference in the number of bank branches (per 1,000 inhabitants) by province. The provinces with the greater number of newly created bank branches are those in the Center-North of Italy. Still, the instrument shows a great deal of variability, even within sub-areas. ${ }^{22}$ The right panel of Figure 2 shows that the 1990-1999 difference in the number of branches in each province is highly correlated, with expected negative sign, with the share of financially constrained firms in that province. OLS and Least Absolute Deviation estimates of the slope of the relationship gives a coefficient of -0.095 (the standard error is 0.039 ) and -0.088 (the standard error is 0.034 ) respectively.

Once we allow for endogeneity of the FC dummy, Equation (1) becomes a standard dummy endogenous variable model. Following Wooldridge (2010), we estimate the model via a two-step procedure: (i) we estimate by maximum likelihood the binary response model $P\left(\mathrm{FC}_{f}=1 \mid \mathbf{X}, \mathrm{Z}\right)$

\footnotetext{
${ }^{20}$ As explained in detail in Section 2, the credit rating is not simply an automatic formula based on quantitative and qualitative data. Rather, it also depends on soft information obtained by the analyst through direct contacts with firms and their the local market.

${ }^{21}$ Transportation costs and the level of competition in the local credit market are other theoretical explanations put forward in the literature to explain why distance may affect the credit supply. See for example Boot and Thakor (2000).

${ }^{22}$ As shown in Figure A4 in the Appendix, the provinces with an higher increase in the number of branches also correspond to provinces where the vast majority of firm is located. In particular: $70 \%$ of firms in the sample are located in the North, $18 \%$ in the Center and $12 \%$ in the South. Robustness checks presented in the following show that our main result is not driven by a simple spatial effect.
} 


\begin{tabular}{lr}
\hline \hline Panel A - Coefficients & \\
$1990-1999$ Difference in \# of bank branches & $-0.625^{* * *}(0.188)$ \\
log TFP & $-0.126^{* * *}(0.023)$ \\
log number of employees & $-0.089^{* * *}(0.016)$ \\
log age & $-0.313^{* * *}(0.016)$ \\
log total assets & $0.228^{* * *}(0.015)$ \\
log gross operating margin & $-0.302^{* * *}(0.008)$ \\
North dummy & $0.260^{* * *}(0.047)$ \\
Center dummy & $0.194^{* * *}(0.053)$
\end{tabular}

\section{Panel B - Goodness of fit}

Number of observations $\quad 39,846$

$\begin{array}{ll}\text { Adjusted } \mathrm{R}^{2} & 0.208\end{array}$

Brier score $\quad 0.072$

AUC score $\quad 0.828$

Notes: Panel A - Probit estimates, the dependent variable is $\operatorname{Pr}(\mathrm{FC}=1)$. Regression includes a constant and 3-digit industry dummies. Estimates on the whole sample of exporters.

Panel B - Goodness of fit statistics. The Brier score is computed as $B S=(1 / N) \sum(\hat{F C}-F C)$, where $\hat{F C}$ is status predicted by the model and $F C$ the actual status: the closer to zero the better the fit. The AUC score measures the area under the ROC (Receiver Operating Characteristics) curve: the closer to 1 the better the predictive power.

Robust standard errors in parenthesis, clustered at provincial level. ***: significant at the $1 \%$ level; **: significant at the $5 \%$ level; *: significant at the $10 \%$ level.

where $\mathbf{X}$ is the above set of firm level controls and $Z$ the instrument, and obtain the associated fitted probabilities $\hat{P}$; next, (ii) we estimate equation (1) by 2 SLS-IV using the fitted probabilities $\hat{P}$ as instrument. There are several nice features of this IV estimator: it is robust to mis-specification of the probit model, it is more efficient than directly including the number of branches opened in 1990-99 as an instrument into an IV procedure and, finally, it does not require to adjust the 2SLS-IV standard errors. $^{23}$

\section{SLS-IV estimates}

In the first step we build $\hat{P}$ via maximum likelihood estimation of the following probit

$$
\mathrm{P}\left(\mathrm{FC}_{f}=1 \mid \mathbf{X}, \mathrm{Z}\right)=\Phi\left(\delta_{1} \mathrm{Z}+\mathbf{X}_{f}^{\prime} \boldsymbol{\beta}+\epsilon_{f}\right)
$$

\footnotetext{
${ }^{23}$ Standard weak instrument diagnostics are known to fail in this context (Nichols, 2007). See the Appendix for a number of further validation of the good properties of the instrument $\hat{P}$.
} 
where the probability to be in the FC group is regressed on the instrument Z, i.e. the 1990-1999 difference in the number of branches in the province wherein a firm is located, and on the set $\mathbf{X}$ of controls employed in the baseline OLS-FE regression above. ${ }^{24}$

Table 3 reports the results. The coefficient on the instrument, $\delta_{1}$, is significant and negative: the more branches opened in a province, the lower the probability for a firm in that province to face tighter financial constraints. Coefficient estimates on the controls tell that more productive, larger, older firms generating higher internal resources are less exposed to credit problems. This is in line with economic intuition. Panel B of Table 3 reports different goodness of fit statistics for the probit model: they do not suggest any specific pathology. ${ }^{25}$

Next, in the second step, we estimate equation (1) via 2SLS-IV taking $\hat{\mathrm{P}}$ as the instrument for the FC dummy. Results are presented in Table 4, with the errors clustered at product-country level. ${ }^{26}$ In column 1 we consider the baseline model over the whole sample of exporters. The instrument works well: it has explanatory power, and we observe here (Panel B) that it is statistically significant in the first stage. In the main regression (Panel A), the estimated coefficient on the FC dummy is 0.580 . This implies that financially constrained firms fix on average $78 \%$ larger unit values than non-FC firms for the same product exported to the same destination country. The elasticities of size and productivity are positive and strongly significant. The coefficient on age is also positive and statistically significant, although the effect is smaller in magnitude. Conversely, availability of collateral and availability of internal resources associate with lower prices. Finally, firms located in the Center-North of Italy tend to show higher unit values.

It is instructive to compare the 2SLS-IV results with the above OLS estimates with productcountry fixed effects (column 2 of Table 2). Without instrumenting, the coefficient on the FC dummy is positive and significant, but smaller than the 2SLS-IV coefficient (0.134 vs. 0.580). There are several explanations for this downward bias of OLS-FE results, all related to possible correlation between the regressors and the endogenous component of the FC proxy. First, OLS-FE estimates might be attenuated if firms with a less stringent financial constraint are also those with higher market power and higher markup. Second, firms that are financially constrained might tend to be less productive on average, and at the same time to produce lower quality goods for which they can charge lower prices. If our control for productivity is not perfect, this might contribute to the downward bias of the OLS-FE.

The positive relationship between financial constraints and export prices is confirmed by a series of robustness checks. These are reported in columns 2-5 of Table $4 .{ }^{27}$ First, we exclude firms with one employee (column 2). These firms represent self-employment, headquarters, or ultimate parent companies in groups. Their export dynamics are thus very specific. The estimated FC coefficient is not statistically different with respect to the baseline results in column 1 within a 1-standard error

\footnotetext{
${ }^{24}$ As before, variables are measured as averages over two consecutive years, and controls are lagged accordingly.

${ }^{25}$ Additional exercises supporting the probit goodness of fit are presented in the Appendix.

${ }^{26}$ Since the instrument is at the province level, in an unreported regression we also cluster standard errors at both product-country and province level. Results, available upon request, do not differ from those reported in the Table.

${ }^{27}$ For each robustness check, the Probit model used to build $\hat{P}$ is correspondingly adapted. Results for these Probit estimates (available upon request) are consistent with those reported in Table 3 above. Further, Table A3 in the Appendix documents the results obtained separately on each year, i.e. without averaging over time. The estimated FC coefficient is positive in all years.
} 


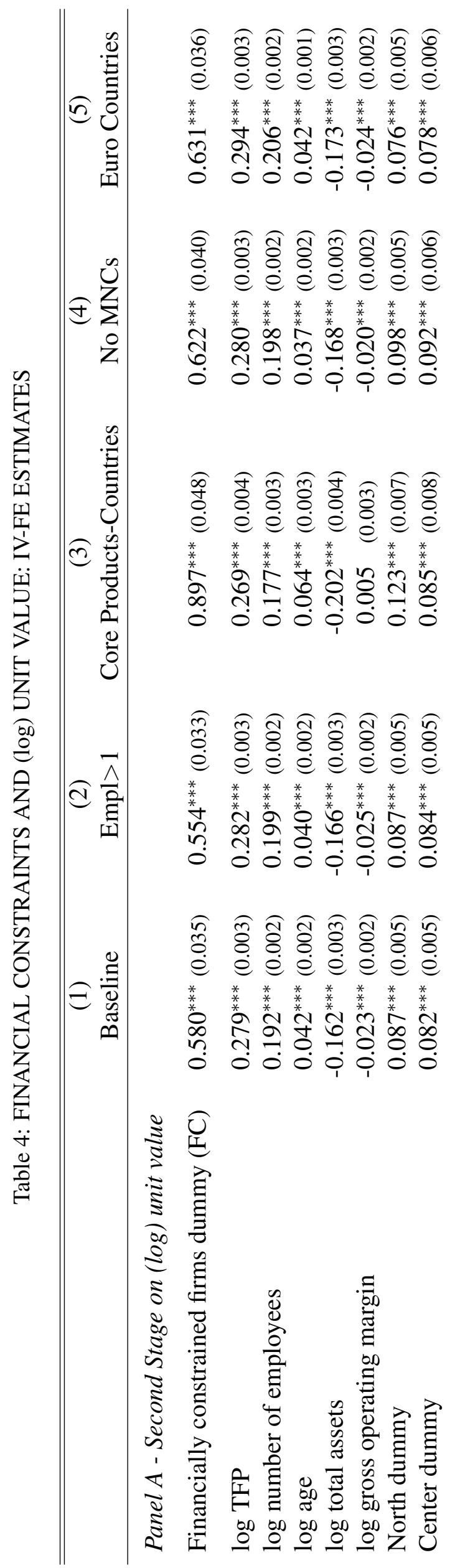

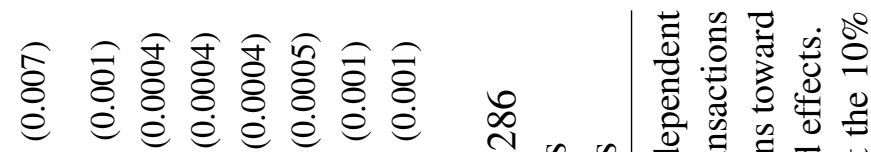

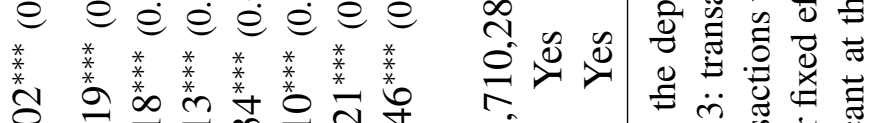

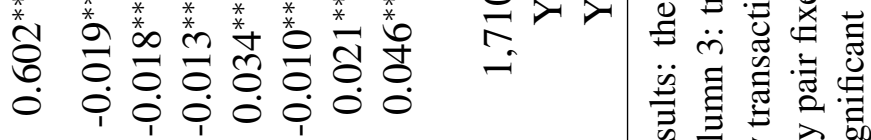
ธิ)

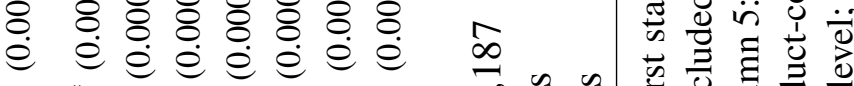

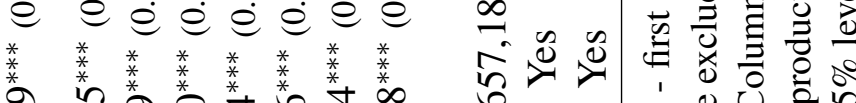

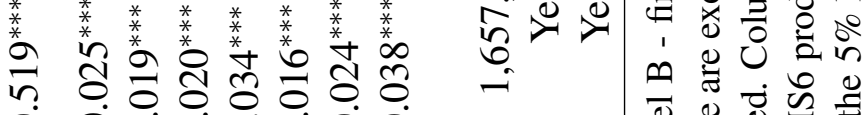
苘

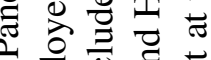
흔

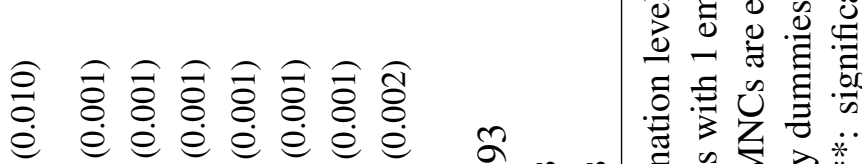

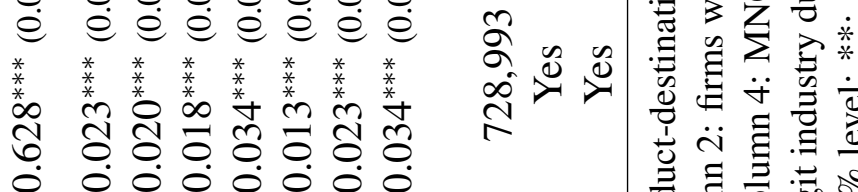

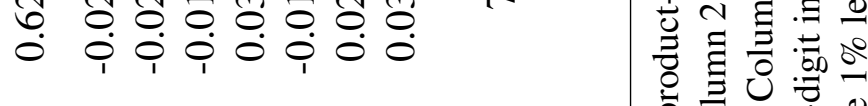

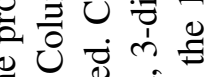

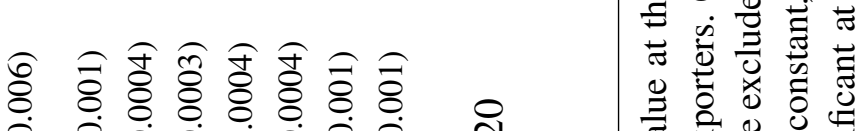
过

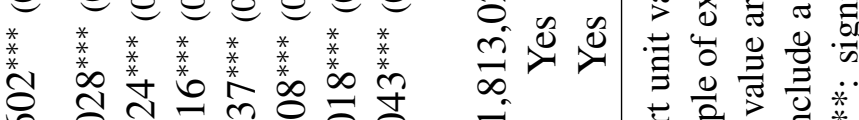
:

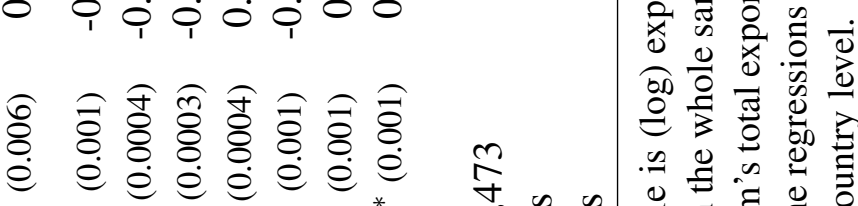

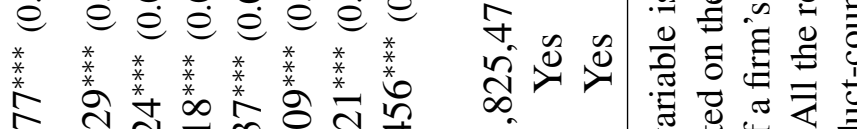

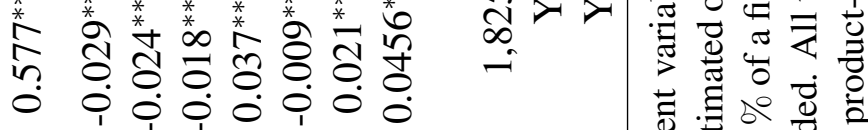

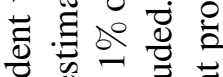
흘 可 웡 o so 要

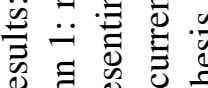

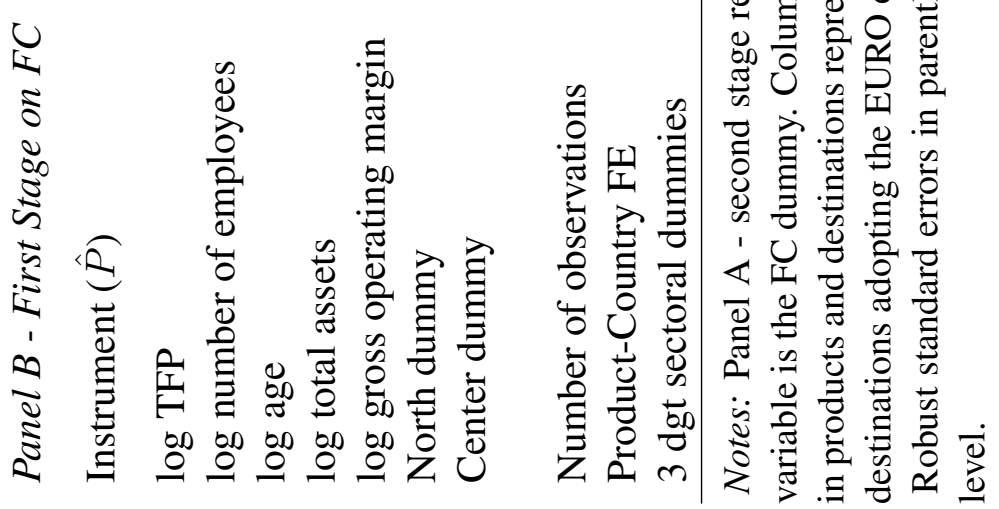


confidence band. Second, we drop marginal products and destinations, defined here as those involving less than $1 \%$ of the overall exports of each firm (column 3). Removing such transactions might make the identification cleaner, as indeed studies on multi-products firms find that products closer to the core firm competencies sell for higher prices than non-core products (Manova and Zhang, 2012b; Eckel et al., 2011). The positive price premium for FC firms is preserved, but the point estimate on the FC dummy coefficient is now statistically larger (0.897) than in full-sample baseline regression. This suggests that constrained firms tend to act even more strongly on the unit values of core products and destinations. Third, in order to account for the potentially particular behavior of multinational companies, which are usually found to set higher prices than domestic firms (cfr. Ge et al., 2013), we drop MNCs from our regression (column 4). Our baseline findings are not affected: the estimated $\gamma$ is higher, but within a 1 standard error confidence band as compared to the full sample results. Finally, in order to eliminate possible confounding factors related to exchange rate dynamics, we re-estimate the model considering only the export transactions to partner countries that use the EURO currency over the entire sample period (column 5). ${ }^{28}$ The point estimate of the FC coefficient (0.631) is larger than in column 1, but it is statistically equal to the baseline estimate within a 1 standard error confidence band.

\section{SLS-IV validation}

We perform further validation exercises of the IV strategy. We control for possible violations of the exclusion restriction, check results against different definitions of the FC status, and provide evidence that results are not driven by a pure geographical effect arising from the observed geographical distribution of our instrument. The results, presented in Table 5, are fairly robust across all these additional exercises and support the main conclusion emerging from the core 2SLS-IV estimates of the previous Section.

Failure of the exclusion restriction may arise from potential correlation between the instrument and idiosyncratic province-level components of the error term that are at the same time related to firms' export pricing strategies. To account for this potential problem, we re-estimate our baseline regression including additional provincial-level control variables capturing factors that may affect firm export prices and correlate with the level of development of the banking sector. In column 1, following Minetti and Zhu (2011), we add the (log of) GDP and population of each province (provided by the Italian Statistical Office), and an index of infrastructural development of Italian provinces obtained from the research conducted by the Association of Italian Chambers of Commerce in collaboration with the "Guglielmo Tagliacarne" Institute. The results are unaffected by the inclusion of these provincial controls: the FC dummy is still positive and statistically significant, and the point estimate is statistically equal (within 1 standard error band) to the baseline estimates. Further, in column 2, we control for the level of financial development of the province at the beginning of the deregulation, by normalizing our instrument for the number of branches in 1990. Also in this case the main result of a positive price premium for FC firms is preserved, and the magnitude is statistically

\footnotetext{
${ }^{28}$ These countries are Austria, Belgium, Finland, France, Germany, Greece, Ireland, Luxembourg, Netherlands, Portugal, and Spain.
} 

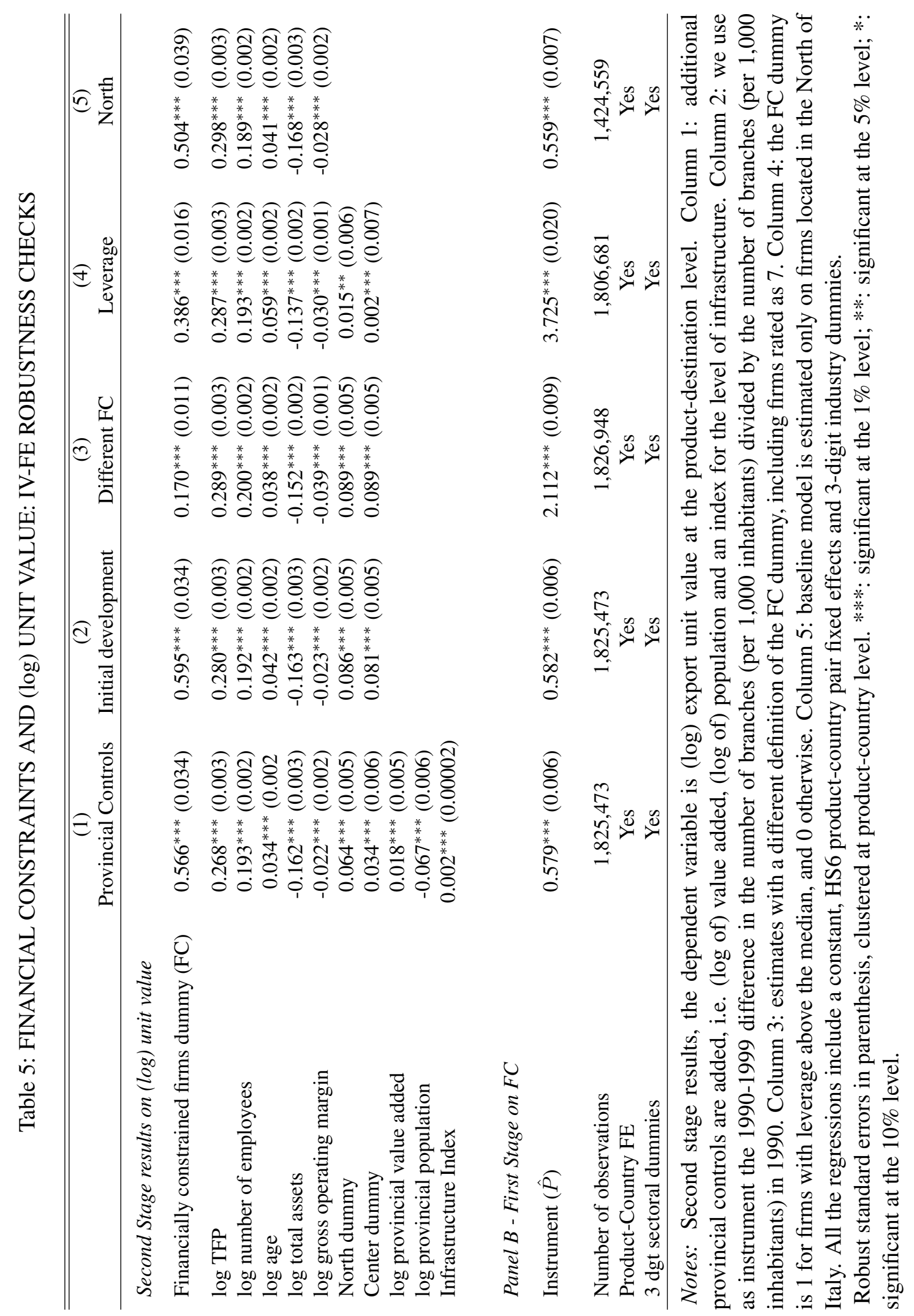
comparable to the baseline regression.

Next, we test the robustness of results to alternative definitions of the FC group. First, in column 3, we include in the definition of the FC class also the firms with a $\mathrm{CB}$ rating of 7 . We observe a sharp reduction in the estimated FC dummy coefficient (0.170), as we expect given the less stringent identification of firms facing inelastic supply of credit. Yet, the positive price premium for FC firms is still there. ${ }^{29}$

Second, in column 4, we base identification of constrained firms on one of the indirect proxies commonly used in the financial constraints literature, that is firm leverage (in terms of assets-to-equity ratio). We create a FC dummy which equals 1 for firms with leverage higher than the median, and zero otherwise. We still get consistent evidence of a strongly statistical significance of the FC price premium.

Finally, there might be a concern about the possible influence of spatial distribution of the instrument, notwithstanding the already pinpointed good deal of geographical variation. We re-estimate the baseline model separately for firms located in the North of Italy. Results are reported in columns 5. We find that there is some interplay with spatial factors, as indeed the FC coefficient for the North sample is somewhat smaller than in the full sample results. Nonetheless, the impact of FCs on prices remains positive and significant, once again confirming our main conclusions.

\section{Discussion}

The message from the regression analysis is that, controlling for firm characteristics, constrained firms sell at higher prices than unconstrained firms exporting within the same product-destination market.

There are different theoretical mechanisms which can explain this finding. The class of industrial organization models of competition in markets with demand rigidities or imperfect consumer adjustment is a candidate. The key logic in these models is that setting high prices is a viable strategy, for firms unable to access external finance, to increase revenues in the attempt to keep financing investment and to meet current liabilities. However, some degree of friction in the product market is needed to allow firms to price above competitors without loosing too much demand. Typical examples of such frictions are switching costs for buyers in moving from one seller to another, for instance in the form of brand loyalty (see the survey in Klemperer, 1995). Same logic underlies models based on the classic customer market model (Phelps and Winter, 1991) which directly postulate a time lag in consumers' reaction to price changes (Gottfries, 2002; Lundin et al., 2009), and applies to models assuming large costs for adjusting quantities (Gagnon, 1989), so that acting on prices is the only viable strategy for constrained firms in the short run. ${ }^{30}$

\footnotetext{
${ }^{29}$ The results are also consistent if we exclude from regression sample the somewhat borderline group of rated-7 firms. The estimated $\gamma$ is 0.512 in this case, results available upon request.

${ }^{30}$ In principle, one can also envisage models where constrained firms choose aggressive pricing (i.e. sell at lower price than unconstrained competitors), seeking to sustain profits by expanding market shares. Models of pricing under financial distress (see for instance Dasgupta and Titman, 1998; Pichler et al., 2008) show that the incentive to raise vs. reduce prices depends on the maturity structure of the debt: the higher the burden of short term repayment, and the higher the probability that distressed firms set higher prices and renounce to market shares in the short run. However, the conjecture that constrained firms can increase international sales and gain market shares seems clearly at odds with the stylised fact in the literature that financial constraints generally associate with a reduction in the margins of export.
} 
To illustrate the key mechanism relating prices and capital market imperfections in these frameworks, consider a simple duopoly where two firms compete over two periods producing the same good with equal marginal costs (or productivity). Assume that there exists a certain degree of product differentiation, and that consumers have to pay a cost if they are willing to switch seller from one period to another. ${ }^{31}$ Switching costs create an incentive for firms to price below the standard marginal cost pricing rule. Indeed, in period 1, firms find it optimal to cut prices and lock-in an higher number of consumers, anticipating that they will be able to charge a monopoly price in the second period. To see the impact of financing problems in this setting, assume that a firm cannot entirely cover operations or investment via internal resources. The same firm can, however, access to external finance through a standard incentive compatible contract. Under the natural assumption that the true cash flow is not observed by the creditor institution, but observed and maybe be diverted to perks or pet projects by managers, the optimal contract foresees full-repayment at end of period 1, and imposes a threat of full liquidation at end of period 1 if the repayment is not met. ${ }^{32}$ This creates a weaker incentive to price below standard marginal costs as compared to the no-imperfections case: since there is now a positive probability that the firm will not meet the contract, the gains from locked-in consumers are now lower in expectations. Given strategic interaction, both constrained and unconstrained firms set a price higher than the price without capital markets imperfections, but this upward distortion is stronger for constrained firms.

Within the international trade literature, theoretical attempts to study financial constraint effects (Muuls, 2008; Manova et al., 2011; Chaney, 2013) provide variations of the Melitz (2003) monopolistic competition model with heterogeneous firms. The model in Fan et al. (2012) is a valid benchmark for the price-constraints links consistent with this literature. The model setting assumes consumers with a standard quality-adjusted CES utility over different varieties of the same good, which entails that, in addition to the standard price-quantity relation, higher quality and more advertised products generate larger demand. On the production side, firms are heterogeneous in productivity and each produce a specific variety of the good with a single input (i.e. labor) technology. Firms face an iceberg trade cost and, following a common approach, the marginal cost of production is an increasing function of quality: higher quality implies higher marginal costs, induced by the hiring of higher quality workers or by investing in R\&D. Moreover, each firm faces two different types of fixed costs: a production fixed cost capturing the fixed investment in quality and a marketing fixed cost modeled as a function of the advertisement intensity capturing all the costs of penetrating into foreign markets. The role of financial constraints is modeled similarly to Manova (2013), so that firms need external capital to finance a fraction of all types of costs (fixed and variable). However, due to financial constraints, firms can borrow only up to a fraction of their cash flow. ${ }^{33}$ Two mechanisms connect prices to financing problems in this set up. First, controlling for productivity, constrained firms sell at higher prices than unconstrained firms to sustain cash flow and ease the constraints. This mechanism is called "price distortion" effect. Here advertisement plays a role similar to consumers' switching costs or any other

\footnotetext{
${ }^{31}$ One can model product differentiation by means of a unit transportation cost, assuming as standard that this represents an opportunity cost payed by consumers if a product in the market does not match her/his ideal variety.

${ }^{32}$ See Chevalier and Scharfstein (1996). Notice that liquidation is an inefficient outcome since firm assets are worth less if managed by the investors.

${ }^{33}$ Predictions do not change if external finance is needed to only cover fixed costs.
} 
source of demand rigidity creating the scope for frictional response of consumers to higher prices. However, there is also a second, "quality adjustment" effect which pushes prices of constrained firms down. Again controlling for productivity, financially constrained firms sell lower quality goods at lower prices since they cannot afford the higher cost of quality. Fan et al. (2012) show that when product quality is endogenously determined the latter effect dominates on the former, leading financially constrained firms to charge lower prices than unconstrained ones. On the contrary, when quality is exogenous constrained firms export at higher prices.

Based on these theoretical considerations, the positive export price premium for constrained firms observed in the analysis is compatible with two alternative explanations. First, that prices set by FC firms are higher because constrained firms revise upward their mark-up over unit costs. That is, there exists only a price distortion effect. Or, second, constrained firms set higher prices because price reduction induced by the choice of producing lower quality goods is crowded out by an increase in the corresponding mark-up. That is, quality adjustment and a price distortion effects coexist, but the latter dominates the former.

In addition to these two channels, and regardless the type of model considered, there might be a third simple explanation based on costs. Indeed, it might be the case that constrained firms operate at higher unit costs, irrespective of the quality level of their products, and thus they charge higher export prices than unconstrained firms just to cover such higher cost of production.

\section{Costs, Mark-up, Quality}

We conclude the paper with a set of empirical investigations that seek to disentangle the relative importance of the three theoretical explanations of the observed price-FCs relationship, at the same time allowing for additional qualifications of our main findings.

Accounting for the costs effect requires to enrich our baseline regression model to include firmlevel proxies of unit costs among the regressors. Part of these costs, the cost of materials in particular, is already captured into our TFP measure. Here we add three further variables, looking for additional channels: the (log of) the unit wage, obtained as the ratio between the total labour expenses and the number of employees, the (log of) the "interest rate" paid by firms, proxied trough the ratio between yearly interest expenses and the stock of financial debt, and a proxy of the unit price of inputs which exploits information on import transactions. Concerning this latter, since one cannot know which particular imported input is used to produce a particular exported product, following Manova and Zhang (2012a) we compute a firm-level index defined as the average of the unit values of a firm's import transactions in intermediate inputs (in logs), demeaned by their product specific averages (computed across firms and destinations) and weighted by the share of each transaction in the overall import revenues of a firm. ${ }^{34}$ Some points are worth noting to appreciate the merits of this measure. First, although it does not reflect the costs of domestic inputs, the price of domestic and imported inputs are typically highly correlated (Kugler and Verhoogen, 2012), and the costs of domestic inputs

\footnotetext{
${ }^{34}$ We identify transactions in intermediate inputs as those involving products that fall into the intermediate input category according to CEPII-BACI classification system (see Gaulier and Zignago, 2010). The results do not change if we instead use data on all imported products.
} 
already enter TFP estimates. Second, although the index can be computed only for importers, thus restricting the sample to two-way traders, we have that in our dataset more than $70 \%$ of exporters are also importers. Third, the index does not only capture unit costs of inputs, but it also allows for an at least indirect control for the quality of inputs, as more costly imported inputs are typically associated to exporters producing more costly and more sophisticated products (see evidence in Manova and Zhang, 2012a).

Column 1 of Table 6 shows the results of 2SLS-IV estimates of the baseline specification augmented with the cost regressors. Constrained firms are confirmed to charge higher prices. As compared to baseline results (column 1 of Table 4), the export price premium of constrained firms is smaller. The magnitude of the reduction (from 0.580 to 0.411 ) suggests that only a relatively small fraction of the observed price premium of FC firms is driven by the cost mechanism. ${ }^{35}$ As expected, all cost variables are positively associated with export prices. The estimate implies that a 100 percentage increase in the average wage translates into an export price rise of about $8.2 \%(0.079 \log$ points $) .{ }^{36}$ The effect of interest rate on export prices has a similar magnitude (coefficient 0.051). Instead, a 100 percent rise in the imported inputs price index is associated with a more sizable increase $(0.31 \log$ points, or $36.3 \%$ ) in export price, suggesting a strong positive correlation between export prices and the price (or the quality) of intermediate inputs. ${ }^{37}$ The results on the other controls are in line with the baseline regression.

Next, we try to improve our understanding of the relative importance of the mark-up or pricedistortion effect vs. the quality adjustment mechanism, by comparing patterns of estimates across horizontally and vertically differentiated products. The rationale behind the exercises is the following. First, irrespective of the existence of quality adjustments, when the varieties of a good provided to the market are highly horizontally differentiated, it is easier for the competing firms to act on prices without drastically affecting their market shares. Accordingly, a stronger mark-up or pricedistortion effect, and thus an higher coefficient on the FC dummy, should be observed within export transactions involving less substitute products. Second, the quality adjustment mechanism, leading constrained firms to export lower quality at lower price, should be stronger in products with high vertical differentiation, where there is greater scope to act on quality differences, than in products where there is narrower or no scope at all for quality up/down-grading. Thus, if adjustments related to quality choices do matter, then we expect a smaller coefficient on the FC dummy in products where vertical differentiation is more important.

To measure the degree of horizontal differentiation of exported products we exploit the classification constructed by Kugler and Verhoogen (2012) using Colombian firm-level data. It is based on dissimilarity component of the full Gallop-Monahn index, which measures dissimilarity of input mixes across firms within an industry. ${ }^{38}$ Industries characterised by an high degree of dissimilarity are those

\footnotetext{
${ }^{35}$ In order to make a proper comparison we also re-run the baseline regression on the reduced sample of two-way traders. The magnitude of the FC coefficient (0.506) is very similar to the full sample estimate reported in column 1 of Table 4.

${ }^{36}$ Note however, that part of the effect is absorbed by TFP. The coefficient on unit wages becomes larger (0.190) if we re-estimate the model excluding TFP from the regressors.

${ }^{37}$ In a similar regression without financial constraints Ge et al. (2013) find that the export price is 0.33 log points higher for firms with an imported inputs price index that is one standard deviation above the sample average.

${ }^{38}$ This is the distance between the expenditure share on each input $i$ in total expenditure of a firm active in a certain
} 


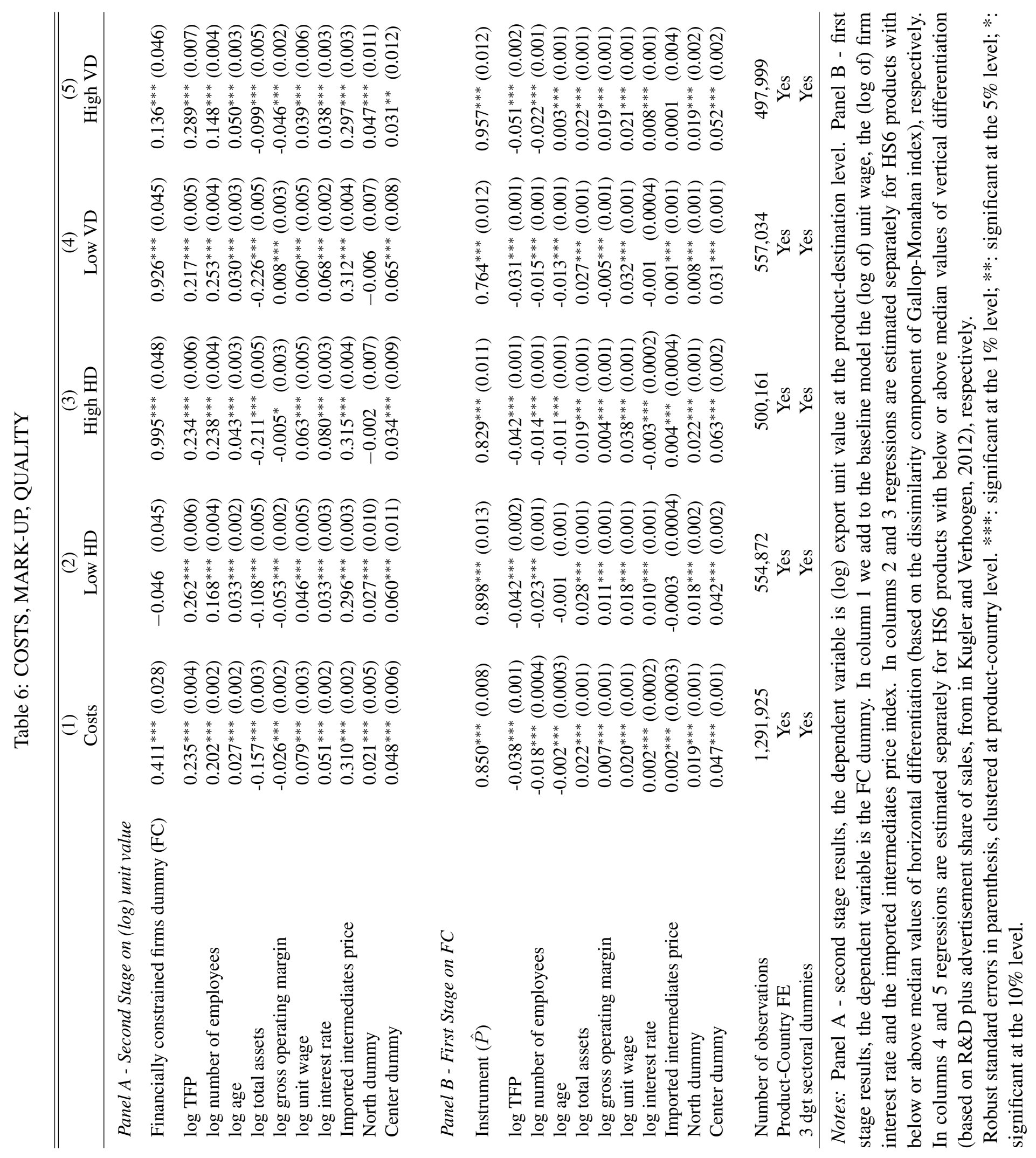


producing products which are less substitute and thus more horizontally differentiated. ${ }^{39}$ To measure vertical differentiation of the export product categories we again follow Kugler and Verhoogen (2012) and employ their classification based on the ratio of advertising plus R\&D expenditures to total sales in U.S. industries. ${ }^{40}$ The logic here is that firms invest more in R\&D and advertising in sectors where it is possible to affect quality and thus there is more scope for quality differentiation. ${ }^{41}$

We re-estimate equation (1) with 2 SLS-IV, separately on different sub-samples of export transactions involving products with different degrees of horizontal or vertical differentiation. Columns 2 and 3 of Table 6 explore the impact of horizontal differentiation. The two groups of High and Low differentiated products are distinguished as the HS6 categories with dissimilarity index above and below the median computed across all HS6 product categories. The coefficient estimates for the FC dummy is not significant in the Low differentiated sub-sample, while it is positive and significant in the High differentiated sample. The point estimate is 0.995 , more than twice as larger as in the unsplitted estimates in column 1 . This magnitude suggests that horizontal differentiation, and the related scope for price-distortion or mark-up effects related to locking-in customers, are indeed strong drivers of pricing strategies.

In columns 4 and 5 of Table 6 we compare 2SLS-IV results across products with High or Low vertical differentiation, respectively defined as HS6 product categories where the vertical differentiation index is above or below the median value computed across all categories. The FC dummy coefficient is positive and quite large (0.926) in the sub-sample of relatively less differentiated products. Conversely, it is still positive, but significantly smaller (0.136) than in the full sample estimate if we take the sub-sample of relatively more vertically differentiated products. This evidence is in agreement with the existence of a quality-adjustment mechanism. Indeed it tells that, when there is more room for quality adjustment, the positive mark-up or price-distortion effect is counteracted by a reduction of the price compatible with constrained firms choosing to export lower quality products at lower prices. Finally, notice that we still include the proxies of unit costs, so that the conclusion on coexistence of the price-distortion vs. quality channels hold for given costs effect.

\section{Conclusion}

The present paper provides a comprehensive analysis of the role that financial constraints play in shaping firms' export prices. We use detailed firm-product-country data on the international activities

industry and the average expenditure share on input $i$ by all firms in the same industry. The sum of these distances weighted by the revenue share of the firm in total industry revenues yields the industry-level measure.

${ }^{39}$ We convert the original ISIC (Rev.2) 4digit level classification of industrial sectors into HS6 product categories through the concordance tables from http://www.macalester.edu/research/economics/page/haveman/Trade.Resources /tradeconcordances.html .

${ }^{40}$ The original data are from the U.S. Federal Trade Commission 1975 Line of Business Survey. Kugler and Verhoogen (2012) convert FTC 4-digit industry classification into ISIC (Rev. 2) 4-digit classification using verbal industry descriptions. We convert from ISIC 4 digit level to HS6 product level using the appropriate concordance tables.

${ }^{41}$ As an additional robustness check, we also employ the Rauch (1999) measure, based on whether a good is traded on a commodity exchange or it has quoted price in industry trade publications. This measures overall differentiation (i.e. both horizontal and vertical). In fact, as argued by Kugler and Verhoogen (2012), although the trade literature has extensively used the Rauch index as a measure of horizontal differentiation, it is indeed unclear which dimension it proxies for. Results are available upon request. 
of a sample of firms covering the vast majority of Italian exporters. The work relates export prices directly to firm-level financial constraint status, by exploiting a firm-level information on a credit rating index internal to the Italian banking system. Moreover, it overcomes an important limitation of previous studies looking at export prices, by adopting an instrumental variable strategy which allows a proper identification of the effect of credit constraints. Thus, the article is the first to establish a causal link from the financial status of exporters to their pricing strategies.

The key finding is that firms facing tighter credit conditions charge higher export prices, even after controlling for key firm attributes and product-destination fixed effects. This price premium for constrained firms is robust to a series of sensitivity analyses. It holds true if we remove firms with only one employee, drop products and destination countries representing negligible shares of a firm's exports, exclude multinational firms, or exclude those transactions operated with a currency different from the Euro. Also, the main message remains unchanged if we experiment with different definitions of the group of constrained firms, or play with the degree of local variation of the data which is key for identification given the provincial-level variability that we exploit in building our instruments. Finally, the main result still comes up if we try to assess its relationship with mark-up strategies and quality, by adding measures of unit costs and by looking at horizontal vs. vertical differentiation.

Our study contributes to the literature documenting the systematic variation in export prices across firms, products and trade partners. The results point out that financial constraints, in addition to efficiency or quality, should be taken into account to explain export price differences across firms. Our main finding points at the co-existence of two mechanisms influencing export prices under financial constraints. A price distortion or mark-up effect that tends to push the price charged by constrained firms up, and an opposing quality adjustment mechanism that induces constrained firms set lower prices. However, we observe that the former effect dominates the latter. This result posits a challenge for the theory. Existing models predict a positive price premium only when quality is exogenous, an assumption that it is hardly met in reality and already disproved by empirical studies. 


\section{Appendix}

\section{The structure of the Italian financial system}

The structure of the Italian financial system presents some peculiarities with respect to other major countries. Figures A1-A3 in this Appendix show that in Italian firms' external financing mainly occurs through banks, partly due to the underdevelopment of bond and stocks markets.

RATIO OF NON-FINANCIAL CORPORATIONS' BANK DEBT TO THEIR FINANCIAL DEBT (1)

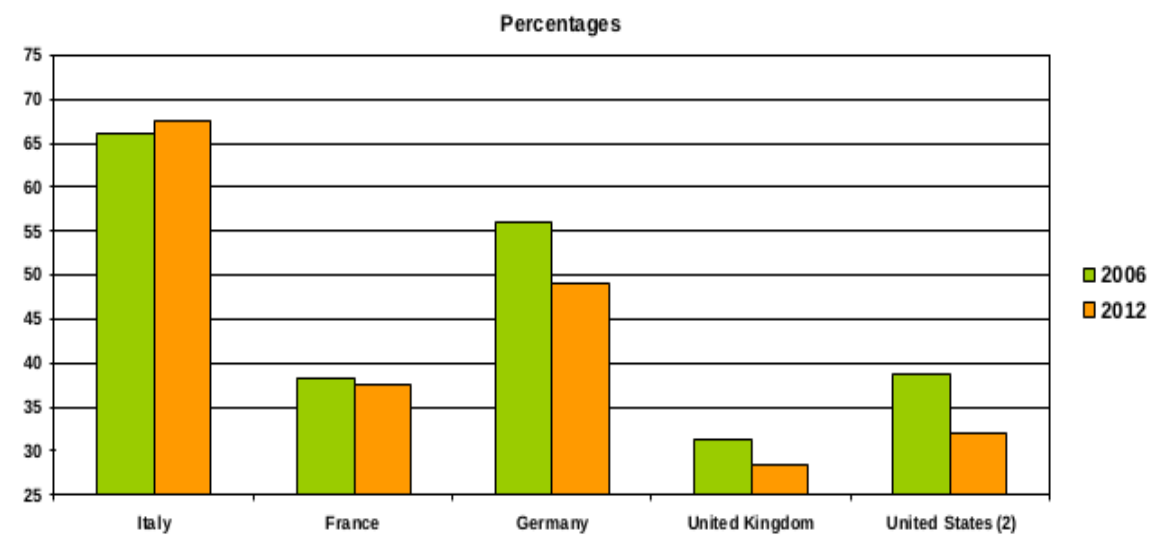

Figure A1. Source: Panetta (2013). Based on data taken from Bank of Italy for Italy; Eurostat and ECB for the euro-area countries; Bank of England for the United Kingdom; Federal Reserve System for the United States. (1) Bank debt comprises only the loans disbursed by the banks resident in each country; (2) 2011 data.

STOCK MARKET CAPITALIZATION OF NON-FINANCIAL CORPORATIONS

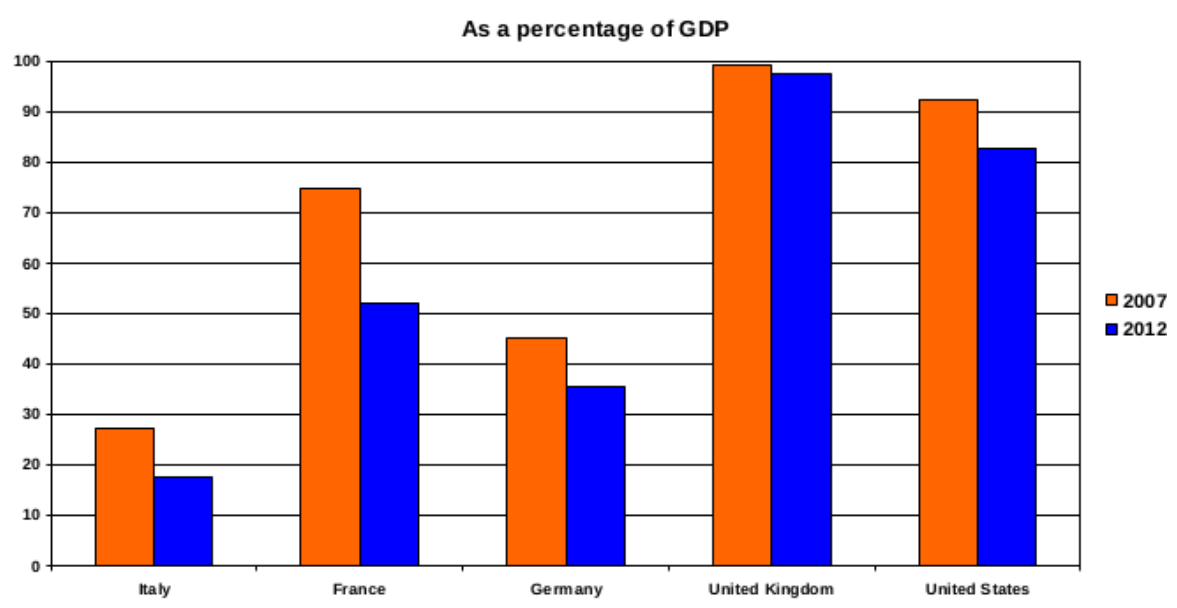

Figure A2. Source: Panetta (2013). Based on Datastream data.

\section{Custom data}

In compliance with the common framework defined by the European Union (EU), there are different requirements in order for a cross-border transaction to be recorded, depending on whether the importing partner is an EU or NON-EU country, and on the value of the transaction. 


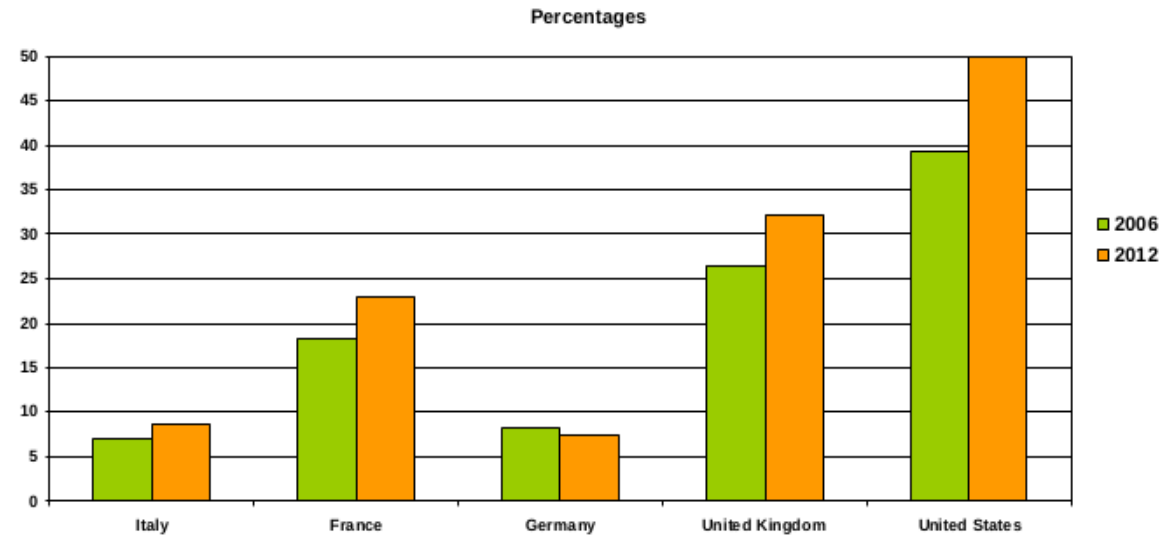

Figure A3. Source: Panetta (2013). Based on data taken from Bank of Italy for Italy; Eurostat and ECB for the euro-area countries; Bank of England for the United Kingdom; Federal Reserve System for the United States.

As far as outside EU transactions are concerned, there is a good deal of homogeneity among member states as well as over time. In the Italian system the information is derived from the Single Administrative Document (SAD) which is compiled by operators for each individual transaction. From the introduction of the Euro, Italy has set a threshold at 620 euro (or $1000 \mathrm{Kg}$ ) for a transaction to be recorded. For all of these recorded extra-EU transactions, the COE data report complete about product category, destination, quantity and value.

Transactions within the EU are collected according to a different system (Intrastat). There the thresholds on the value of transactions qualifying for complete record are less homogeneous across EU member states, with direct consequences on the type of information reported in the data. In 2003 (the last year covered in the analysis), there are two cut-offs. If a firm has more than 200,000 euro of exports (based on previous year report), then she must fill the Intrastat document monthly. This implies that complete information about product types is also available. Instead, if previous year export value falls in between 40,000 and 200,000 euro, the quarterly Intrastat file has to be filled, implying that only the amount of export is recorded, while information on the product is not. Firms with previous year exports below 40,000 euro are not required to report any information on trade flows. According to ISTAT, although only one-third of the operators submitted monthly declarations, these firms cover about $98 \%$ of trade flows (http://www.coeweb.istat.it/default.htm). Thus, firms which do not appear in COE are either marginal exporters or do not export at all.

\section{Representativeness}

Table A1 shows that the representativeness of the dataset is quite satisfactory. We report here 2003 data, but figures are comparable in the other years. As mentioned in the main text, although the dataset includes only about $20 \%$ of manufacturing in terms of number of firms, we cover about $60 \%$ of manufacturing firms that do export, and about $84 \%$ of the total value of manufacturing exports. We add here that these number are also basically stable across different industrial sectors.

This picture is explained by the well known abundance of micro and small firms in Italian manu- 
facturing, together with the observation that the legal status of limited firm tends to be more common across medium-bigger firms, and medium-big firms are expected to account for the great bulk of overall export activities in the country, in line with a well established result in the literature. In agreement with this, Table A2 shows that (again for 2003 but valid across other sample years) the firms in our sample are on average slightly bigger and more productive (in terms of labour productivity here) than the population of manufacturing firms. At the same time, however, we do not observe big differences when we focus on exporting firms: the average size, labour productivity, export values, number of exported products and number of destinations served do not differ significantly between our sample and the population.

Table A1. COVERAGE OF THE DATASET, MANUFACTURING: NUMBER OF FIRMS; NUMBER OF EXPORTERS, EXPORT VALUE (2003)

\begin{tabular}{|c|c|c|c|c|c|c|c|c|c|}
\hline \multirow[b]{2}{*}{ Sector } & \multicolumn{3}{|c|}{ ALL FIRMS } & \multicolumn{3}{|c|}{ EXPORTERS } & \multicolumn{3}{|c|}{ EXPORT VALUE } \\
\hline & $\begin{array}{l}\text { ASIA-COE } \\
\text { (Number) }\end{array}$ & $\begin{array}{l}\text { Our dataset } \\
\text { (Number) }\end{array}$ & $\begin{array}{c}\text { Coverage } \\
\%\end{array}$ & $\begin{array}{l}\text { ASIA-COE } \\
\text { (Number) }\end{array}$ & $\begin{array}{c}\text { Our dataset } \\
\text { (Number) }\end{array}$ & $\begin{array}{c}\text { Coverage } \\
\%\end{array}$ & $\begin{array}{l}\text { ASIA-COE } \\
\text { (billion) }\end{array}$ & $\begin{array}{c}\text { Our dataset } \\
\text { (billion) }\end{array}$ & $\begin{array}{c}\text { Coverage } \\
\%\end{array}$ \\
\hline 15 & 71345 & 8882 & 12.45 & 4927 & 2872 & 58.36 & 12.1 & 9.4 & 77.77 \\
\hline 17 & 27762 & 6408 & 23.08 & 5681 & 3445 & 60.69 & 12.5 & 10.8 & 86.70 \\
\hline 18 & 41615 & 6134 & 14.74 & 5035 & 2654 & 52.73 & 9.7 & 8.1 & 83.56 \\
\hline 19 & 21985 & 4495 & 20.45 & 5688 & 2644 & 46.48 & 10.8 & 8.8 & 81.62 \\
\hline 20 & 46584 & 3550 & 7.62 & 2458 & 978 & 39.79 & 1.5 & 1.3 & 83.88 \\
\hline 21 & 4566 & 1951 & 42.73 & 1328 & 884 & 66.57 & 4.0 & 3.8 & 95.28 \\
\hline 22 & 27344 & 7801 & 28.53 & 2164 & 1237 & 57.26 & 1.7 & 1.6 & 91.25 \\
\hline 23 & 443 & 333 & 75.17 & 84 & 72 & 86.90 & 3.8 & 3.7 & 99.25 \\
\hline 24 & 6127 & 3529 & 57.60 & 2595 & 1984 & 76.61 & 22.6 & 16.3 & 71.80 \\
\hline 25 & 13084 & 5575 & 42.61 & 4422 & 2968 & 67.18 & 10.4 & 8.9 & 85.72 \\
\hline 26 & 27230 & 6218 & 22.84 & 4522 & 2176 & 48.12 & 7.2 & 6.2 & 86.18 \\
\hline 27 & 3814 & 1893 & 49.63 & 1335 & 1016 & 76.10 & 9.9 & 8.7 & 88.21 \\
\hline 28 & 99519 & 19551 & 19.65 & 10280 & 5754 & 56.17 & 12.6 & 11.2 & 89.26 \\
\hline 29 & 42391 & 14710 & 34.70 & 12128 & 8177 & 67.55 & 43.3 & 38.0 & 87.61 \\
\hline 30 & 1976 & 822 & 41.60 & 262 & 185 & 70.61 & 1.5 & 1.3 & 91.19 \\
\hline 31 & 18316 & 5315 & 29.02 & 3214 & 2128 & 66.30 & 8.1 & 6.6 & 82.12 \\
\hline 32 & 8671 & 1665 & 19.20 & 911 & 608 & 66.85 & 5.2 & 3.7 & 71.02 \\
\hline 33 & 22399 & 3073 & 13.72 & 1921 & 1355 & 70.68 & 4.6 & 3.9 & 85.18 \\
\hline 34 & 1962 & 1122 & 57.19 & 918 & 687 & 74.84 & 17.8 & 15.3 & 85.86 \\
\hline 35 & 4684 & 1541 & 32.90 & 819 & 475 & 60.81 & 6.7 & 4.9 & 73.84 \\
\hline 36 & 50018 & 7873 & 15.74 & 8664 & 4193 & 48.42 & 12.1 & 10.4 & 85.96 \\
\hline Total & 541835 & 112441 & 20.75 & 79356 & 46492 & 58.69 & 218.1 & 183.0 & 83.93 \\
\hline
\end{tabular}

Notes: The Table reports, for 2003, the number of firms, the number of exporters and the export value by sector for the entire population of Italian manufacturing firms (ASIA-COE dataset) and the limited liabilities firms (our dataset). Sector definition according to 2-digit NACE manufacturing industries.

Table A2. DESCRIPTIVE STATISTICS, 2003

\begin{tabular}{lcccccc}
\hline & \multicolumn{3}{c}{ ASIA-COE } & \multicolumn{3}{c}{ Our Dataset } \\
& Mean & Sd & Observations & Mean & Sd & Observations \\
\hline log number of employees & 2.43 & 1.35 & 79356 & 2.85 & 1.32 & 46492 \\
log export & 11.61 & 2.74 & 79356 & 12.43 & 2.67 & 46492 \\
Number of products & 8.04 & 14.7 & 79356 & 10.8 & 17.0 & 46492 \\
Number of destinations & 8.77 & 12.9 & 79356 & 11.7 & 14.7 & 46492 \\
\hline
\end{tabular}

Notes: The Table reports, for 2003, basic descriptive statistics for the entire population of Italian manufacturing firms (ASIA-COE dataset) and for limited liabilities firms (our dataset). 


\section{Distributions of firms by province}

Figure A4 shows the geographical distribution of the number of firms (left panel) and of the share of constrained firms (right panel) across Italian provinces. The darker a province in the map and the higher the corresponding figure in the province.
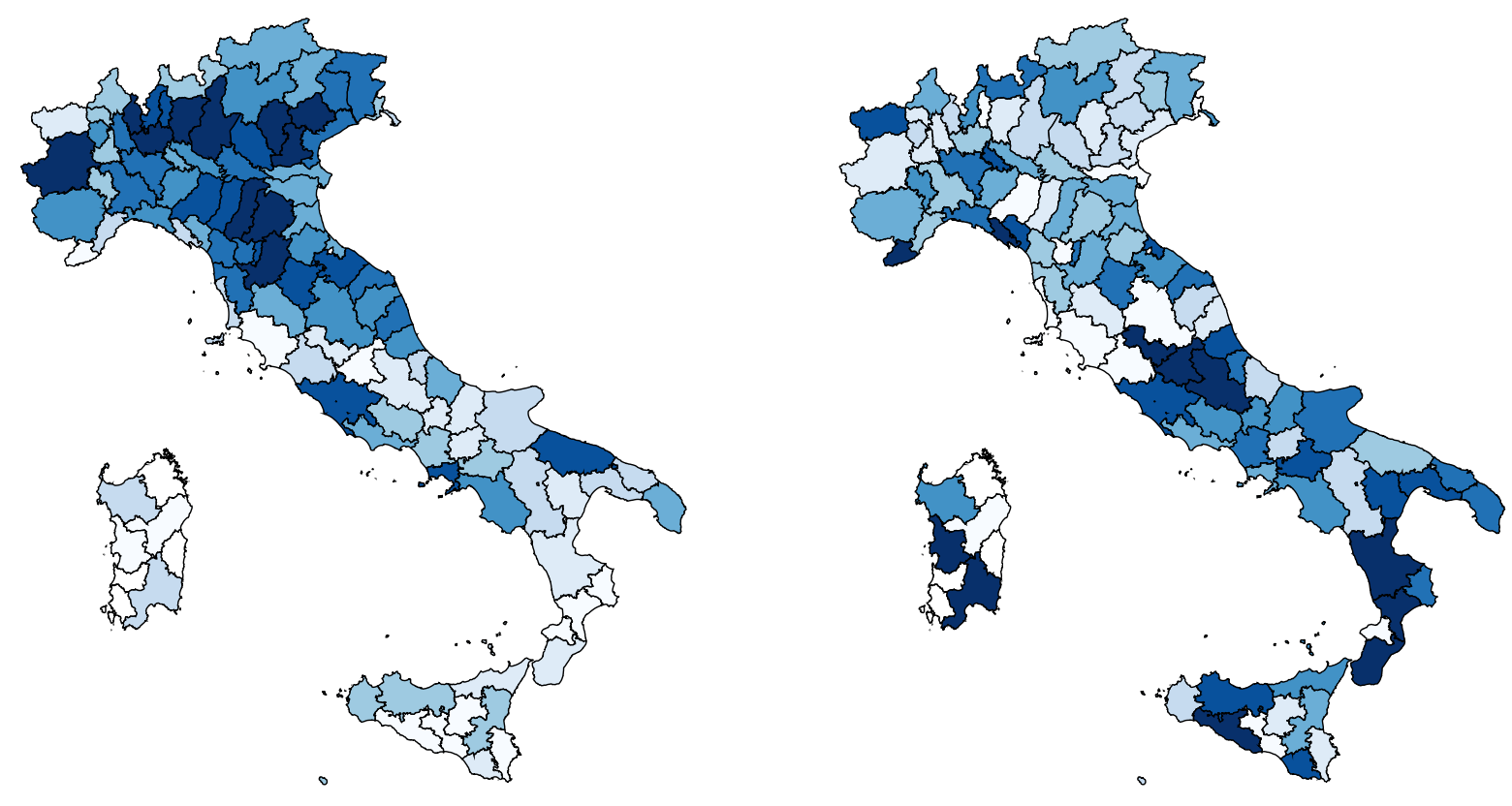

Figure A4. Distribution across provinces of the number of firms (left) and of the share of FC firms (right).

\section{Probit Goodness of fit}

The 2SLS-IV estimator employed in the paper follows Procedure 21.1 in Wooldridge (2010). To recall, the procedure entails a two stage estimator for the dummy endogenous variable model in equation 1. First, estimate by maximum likelihood the binary response model $P\left(\mathrm{FC}_{f}=1 \mid \mathbf{X}, \mathrm{Z}\right)$ where $\mathbf{X}$ are firm level controls and $Z$ the instrument, and obtain the associated fitted probabilities $\hat{P}$; Second, estimate equation 1 by 2SLS-IV using the fitted probabilities $\hat{P}$ as instrument.

As explained in the main text, to build $\hat{P}$ we estimate by maximum likelihood the following probit

$$
\mathrm{P}\left(\mathrm{FC}_{f}=1 \mid \mathbf{X}, \mathrm{Z}\right)=\Phi\left(\delta_{1} \mathrm{Z}+\mathbf{X}_{f}^{\prime} \boldsymbol{\beta}+\epsilon_{f}\right)
$$

where the probability of being financially constrained is regressed on $\mathrm{Z}$, the average number of new branches opened annually between 1990-98, and on X, the set of firm level controls.

Although this IV estimator enjoys several good properties, the standard weak instrument diagnostics fail in this context. We provide here a series of alternative assessment of the goodness of fit of the probit, supporting the validity of the instrument.

The upper panel of Figure A5 reports separation plot (Greenhill et al., 2011), a simple visual technique for assessing the predictive power of models with binary outcomes. Its main advantage is that it does not depend on the often arbitrary choice of a probability threshold to distinguish between 
predicted positive and negative events. The separation plot reports on the x-axis the fitted probabilities of observing a positive outcome $\hat{\mathrm{P}}(\mathrm{FC}=1)$ and it associates to each value of $\hat{P}$ the actual value of the dummy FC. The starker the separation between the colored and uncolored areas the better the goodness of fit of the model. As a reference of how the separation plot looks like when there is lower predictive power, the bottom panel of Figure A5 reports the result for a model with only one control (age in this case). The improvement in the prediction ability from adding relevant controls is clear-cut.
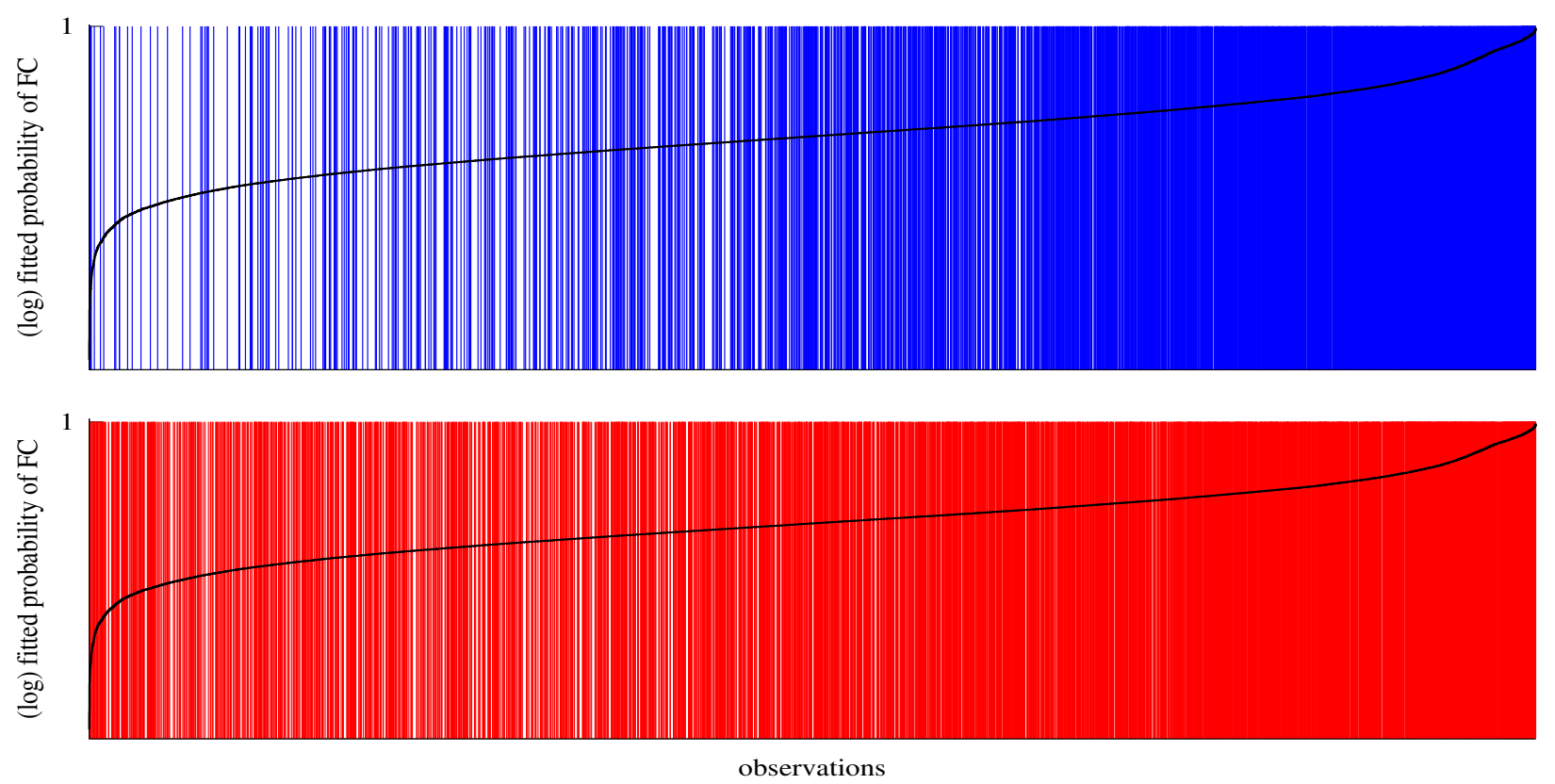

Figure A5: PROBIT SEPARATION PLOT

In the main text (Panel B of Table 3) we report three other goodness of fit statistics: a standard Adjusted- $\mathrm{R}^{2}$, the Brier score, calculated as $B S=(1 / N) \sum(\hat{F C}-F C)$ where $\hat{F C}$ is status predicted by the model and $F C$ the actual status, and the AUC scores. The AUC score measure the area under the ROC (Receiver Operating Characteristics) curve. This curve represents the relation between the false positive rate (FPR) of the model and its true positive rate (TPR). Ideally, one would like to have a model with a TPR equal to 1 and a FPR equal to 0 . In practice, the closer the ROC curve to the border of the unit-length square, the higher the AUC score and the higher the ability of the model to forecast the event under scrutiny. In Figure A6 we present the ROC curve from estimates of Equation 3, clearly supporting a high predictive power of the model.

\section{Yearly estimates}

Table A3 reports results of estimates of the baseline regression model

$$
\ln \mathrm{EUV}_{f p c, t}=\gamma \mathrm{FC}_{f, t-1}+\mathbf{X}_{f, t-1}^{\prime} \boldsymbol{\beta}+\mu_{p c}+\epsilon_{f p c, t}
$$

performed separately on each year. The FC dummy coefficient is positive and significant in all years. This shows that averaging the data over time has the only effect to smooth yearly-specific shocks, 


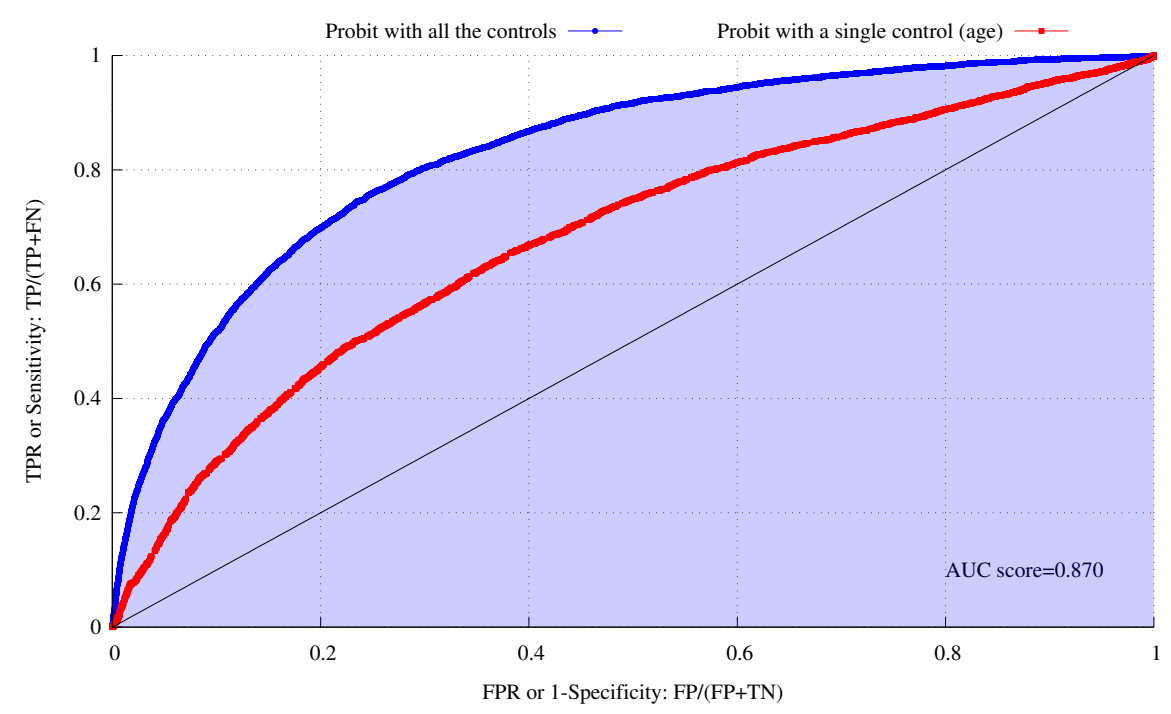

Figure A6: ROC PLOT

while the main result is preserved.

Table A3 - FINANCIAL CONSTRAINTS AND $(\log )$ UNIT VALUE: IV-FE BY YEAR

\begin{tabular}{lccc}
\hline \hline & $(1)$ & $(2)$ & $(3)$ \\
& 2001 & 2002 & 2003 \\
\hline Second Stage on (log) unit value & & & \\
Financially constrained firms dummy (FC) & $0.753^{* * *}(0.032)$ & $0.627^{* * *}(0.035)$ & $0.486^{* * *}(0.032)$ \\
log TFP & $0.279^{* * *}(0.003)$ & $0.299^{* * *}(0.003)$ & $0.296^{* * *}(0.003)$ \\
log number of employees & $0.178^{* * *}(0.003)$ & $0.184^{* * *}(0.002)$ & $0.180^{* * *}(0.002)$ \\
log age & $0.038^{* * *}(0.002)$ & $0.035^{* * *}(0.002)$ & $0.040^{* * *}(0.002)$ \\
log total assets & $-0.151^{* * *}(0.002)$ & $-0.150^{* * *}(0.002)$ & $-0.145^{* * *}(0.002)$ \\
log gross operating margin & $-0.023^{* * *}(0.001)$ & $-0.032^{* * *}(0.001)$ & $-0.041^{* * *}(0.00)$ \\
North dummy & $0.101^{* * *}(0.006)$ & $0.106^{* * *}(0.006)$ & $0.116^{* * *}(0.005)$ \\
Center dummy & $0.100^{* * *}(0.006)$ & $0.103^{* * *}(0.006)$ & $0.114^{* * *}(0.006)$ \\
& & & \\
Number of observations & $1,091,249$ & $1,196,947$ & $1,168,909$ \\
Product-Country FE & Yes & Yes & Yes \\
3 dgt sectoral dummies & Yes & Yes & Yes \\
\hline
\end{tabular}

Notes: Second stage results, the dependent variable is $(\log )$ export unit value at the product-destination level. Regression in column 1 estimated using 2001, in column 2 using 2002, and in column 3 using 2003. All the regressions include a constant, HS6 product-country pair fixed effects and 3-digit industry dummies.

Robust standard errors in parenthesis, clustered at product-country level. ***: significant at the $1 \%$ level; **: significant at the $5 \%$ level; *: significant at the $10 \%$ level. 


\section{Acknowledgements}

The present work has been possible thanks to a research agreement between the Italian Statistical Office (ISTAT) and the Scuola Superiore Sant'Anna. We are grateful to seminar participants at Paris School of Economics, OFCE (Valbonne), Centro Studi Luca d'Agliano and Rocky Mountain Empirical Trade Conference for all the useful feedback we received. Angelo Secchi gratefully acknowledges the Paris School of Economics for granting him a 'Residence de Recherche' for the period 20122014. Chiara Tomasi gratefully acknowledges financial support by the Marie Curie Program Grant COFUND Provincia Autonoma di Trento. We also acknowledge financial support from the Institute for New Economic Thinking, INET inaugural grant \#220. 


\section{References}

Alessandrini, P., A. F. Presbitero, And A. Zazzaro (2009): "Banks, Distances and Firms' Financing Constraints," Review of Finance, 13, 261-307.

(2010): "Bank size or distance: what hampers innovation adoption by SMEs?" Journal of Economic Geography, 10, 845-881.

Amiti, M. And D. E. Weinstein (2011): "Exports and Financial Shocks," The Quarterly Journal of Economics, 126, 1841-1877.

BAstos, P. AND J. Silva (2010): “The quality of a firm's exports: Where you export to matters," Journal of International Economics, 82, 99-111.

Bellone, F., P. Musso, L. Nesta, And S. Schiavo (2010): "Financial Constraints and Firm Export Behaviour," The World Economy, 33, 347-373.

Benfratello, L., F. Schiantarelli, And A. Sembenelli (2008): "Banks and innovation: Microeconometric evidence on Italian firms," Journal of Financial Economics, 90, 197-217.

BERMAN, N. AND J. HRICOURT (2010): "Financial factors and the margins of trade: Evidence from cross-country firm-level data," Journal of Development Economics, 93, 206-217.

Berman, N., P. Martin, And T. MAYer (2012): "How do Different Exporters React to Exchange Rate Changes?" The Quarterly Journal of Economics, 127, 437-492.

BONACCORSI Di PATTI, E. AND G. GOBBI (2001): "The changing structure of local credit markets: Are small businesses special?" Journal of Banking \& Finance, 25, 2209-2237.

Boot, A. W. A. And A. V. Thakor (2000): “Can Relationship Banking Survive Competition?" Journal of Finance, 55, 679-713.

Bottazzi, G., A. Secchi, and F. Tamagni (2008): "Productivity, Profitability and Financial performance," Industrial and Corporate Change, 17, 711-751.

(2013): "Financial constraints and firm dynamics," Small Business Economics, forthcoming.

CARling, K. AND S. Lundberg (2005): "Asymmetric information and distance: an empirical assessment of geographical credit rationing," Journal of Economics and Business, 57, 39-59.

Chaney, T. (2013): “Liquidity Constrained Exporters," Working Paper 19170, National Bureau of Economic Research.

Chevalier, J. A. And D. S. Scharfstein (1996): "Capital market imperfections and countercyclical markups: theory and evidence," American economic review, 86, 703-725.

ChOR, D. AND K. Manova (2012): "Off the cliff and back? Credit conditions and international trade during the global financial crisis," Journal of International Economics, 87, 117-133. 
Dasgupta, S. And S. Titman (1998): "Pricing Strategy and Financial Policy," Review of Financial Studies, 11, 705-37.

Eckel, C., L. Iacovone, B. Javorcik, And J. P. NeAry (2011): "Multi-Product Firms at Home and Away: Cost- versus Quality-based Competence," CEPR Discussion Papers 8186, C.E.P.R. Discussion Papers.

FAN, H., E. L.-C. LAI, AND Y. A. Li (2012): “Credit Constraints, Quality, and Export Prices: Theory and Evidence from China," MPRA Paper 40857, University Library of Munich, Germany.

FARre-Mensa, J. AND A. LJUngQVist (2013): “Do measures of Financial Constraints Measure Financial Constraints?” NBER Working Paper 19551, National Bureau of Economic Research.

FeEnstra, R. C., Z. LI, And M. Yu (2011): "Exports and Credit Constraints Under Incomplete Information: Theory and Evidence from China," NBER Working Papers 16940, National Bureau of Economic Research, Inc.

Fligner, M. A. AND G. E. Policello (1981): "Robust rank procedures for the Behrens-Fisher problem," Journal of the American Statistical Association, 76, 141-206.

GAGnON, J. E. (1989): "Adjustment costs and international trade dynamics," Journal of International Economics, 26, 327-344.

Gaulier, G. And S. Zignago (2010): "BACI: International Trade Database at the Product-Level. The 1994-2007 Version,” Working Papers 2010-23, CEPII research center.

Ge, Y., H. LAI, And S. C. Zhu (2013): "Multinational Price Premium," mimeo, Department of Economics, Michigan State University.

Gottfries, N. (2002): "Market Shares, Financial Constraints and Pricing Behaviour in the Export Market," Economica, 69, 583-607.

Greenaway, D., A. Guariglia, and R. Kneller (2007): "Financial factors and exporting decisions," Journal of International Economics, 73, 377-395.

Greenhill, B., M. D. WARD, AND A. SACKS (2011): "The separation plot: a new visual method for evaluating the fit of binary models," American Journal of Political Science, 55, 990-1002.

Guiso, L., L. Pistaferri, AND F. Schivardi (2013): “Credit within the Firm," Review of Economic Studies, 80, 211-247.

Guiso, L., P. SAPIEnZA, And L. Zingales (2004): “Does Local Financial Development Matter?” The Quarterly Journal of Economics, 119, 929-969.

_ (2006): “The Cost of Banking Regulation,” NBER Working Papers 12501, National Bureau of Economic Research, Inc. 
Harrigan, J., X. MA, AND V. ShlychKov (2011): “Export Prices of U.S. Firms,” NBER Working Paper 17706, National Bureau of Economic Research.

Herrera, A. M. And R. Minetti (2007): "Informed finance and technological change: Evidence from credit relationships," Journal of Financial Economics, 83, 223-269.

KLEMPERER, P. (1995): “Competition when consumers have switching costs: an overview with applications to industrial organization, macroeconomics and international trade," Review of Economic Studies, 62, 515-539.

Kremp, E. And P. Sevestre (2012): "Did the crisis induce credit rationing for French SMEs?" Working papers 405, Banque de France.

Kugler, M. And E. Verhoogen (2012): “Prices, Plant Size and Product Quality," Review of Economic Studies, 79, 307-339.

Levchenko, A. A., L. T. Lewis, And L. L. Tesar (2010): “The Collapse of International Trade During the 2008-2009 Crisis: In Search of the Smoking Gun," IMF Economic Review, 58, 214-253.

LI, Z. AND M. YU (2009): "Exports, Productivity, and Credit Constraints: A Firm-Level Empirical Investigation of China," Global COE Hi-Stat Discussion Paper Series gd09-098, Institute of Economic Research, Hitotsubashi University.

Lundin, M., N. GotTfries, C. Bucht, And T. Lindstrm (2009): "Price and Investment Dynamics: Theory and Plant-Level Data," Journal of Money, Credit and Banking, 41, 907-934.

Manova, K. (2013): “Credit Constraints, Heterogeneous Firms, and International Trade," Review of Economic Studies, 80, 711-744.

MANOVA, K., S.-J. WEI, AND Z. ZHANG (2011): “Firm Exports and Multinational Activity Under Credit Constraints," NBER Working Papers 16905, National Bureau of Economic Research, Inc.

Manova, K. And Z. Zhang (2012a): “Export Prices across Firms and Destinations," Quarterly Journal of Economics, 127, 379-436.

_ (2012b): "Multi-Product Firms and Product Quality," NBER Working Paper 18637, National Bureau of Economic Research.

Melitz, M. J. (2003): “The Impact of Trade on Intra-Industry Reallocations and Aggregate Industry Productivity," Econometrica, 71, 1695-1725.

MinetTi, R. AND S. C. ZHU (2011): “Credit constraints and firm export: microeconomic evidence from Italy," Journal of International Economics, 83, 109-125.

Muuls, M. (2008): “Exporters and Credit Constraints. A Firm-Level Approach,” Working Paper Research 2008-139, National Bank of Belgium.

Nichols, A. (2007): “Causal inference with observational data," Stata Journal, 7, 507-541(35). 
PAnetTA, F. (2013): “Banks, Finance, Growth,” mimeo, Bank of Italy.

PanetTa, F., F. Schivardi, And M. Shum (2009): “Do mergers improve information? Evidence from the loan market," Journal of Money, Credit and Banking, 41, 673-709.

Petersen, M. (2004): “Information: Hard and soft,” Working papers, Northwestern University.

Petersen, M. A. And R. G. Rajan (1995): “The Effect of Credit Market Competition on Lending Relationships," The Quarterly Journal of Economics, 110, 407-43.

Phelps, E. S. AND S. G. Winter (1991): "Optimal Price Policy under Atomistic Competition,” in Microeconomic Foundations of Employment and Inflation Theory, ed. by E. S. Phelps, New York : Norton.

Pichler, P., A. Stomper, And C. Zulehner (2008): "Why Leverage Affects Pricing," Review of Financial Studies, 21, 1733-1765.

RAUCH, J. E. (1999): "Networks versus markets in international trade," Journal of International Economics, 48, 7-35.

Silverman, B. W. (1986): Density Estimation for Statistics and Data Analysis (Chapman \& Hall/CRC Monographs on Statistics \& Applied Probability), Chapman and Hall/CRC.

STRASSER, G. (2013): "Exchange rate pass-through and credit constraints," Journal of Monetary Economics, 60, 25-38.

WoOLDRIDGE, J. M. (2009): “On estimating firm-level production functions using proxy variables to control for unobservables," Economics Letters, 104, 112 - 114. (2010): Econometric Analysis of Cross Section and Panel Data, Cambridge, MA: The MIT Press. 